\title{
Copyright as International Cultural Policy: A New Model for Copyright Enforcement in China
}

\author{
Patrick Hughes*
}

China's copyright regime, which American businesses have repeatedly complained is not sufficiently enforced, could be successfully encouraged through a cultural policy, as an alternative to a trade policy. Through a cultural perspective, the concept of copyright might not be as remote to China's populace as was once believed, as people can no longer blame the influence of Confucianism or suppression of private property rights. This article explores the cultural policies of the United States and China to discover a way by which a copyright system can be inherently Chinese in nature, and therefore, more likely to be enforced.

\section{Introduction}

On the advent of the 2008 Olympic Games, China has achieved the status of major world power that has been described by Time magazine as having a "growing clout and visibility" that accompanies an "increased sense that it should adhere to the highest standards of international conduct." 1 As a world power, China's international responsibilities include adherence to international standards for the protection of copyrights, as well as other intellectual property (IP) rights. ${ }^{2}$ Although China has joined many international treaties to comply with these standards, and has signed nine memoranda of understanding, copyright enforcement in compliance with these treaties

* Freelance artistic consultant. J.D.(The George Washington Univ.); M.A.(Columbia Univ.), B.A.(Univ. of Minnesota). Mr. Hughes is living in New York City.

1 Simon Elegant, China Comes Out to Play, Time, Oct. 1, 2007, at 46.

22007 Report to Congress of the U.S.-China Economic and Security Review Commission, 110 Congress (1st Session) 32, November 2007, available at http://www.uscc.gov/annual_report/2007/report_to_congress.pdf. [hereinafter 2007 Report of U.S.-China Commission]. 
has remained weak. ${ }^{3}$ This situation has emerged from the belief that many holdincluding a senior Chinese official - that such enforcement is not at this time in China's interest. 4 In direct contrast with this notion, here are three Chinese people who hold that it is indeed in China's interest to have copyrights protected-both in China and abroad.

The first is Vivien Sung, author of Five-fold Happiness: Chinese concepts of luck, prosperity, longevity, happiness, and wealth, in English with a translation into traditional Chinese on either the same page or on an opposite page. ${ }^{5}$ While the book is available throughout the English-speaking world, it is manufactured, distributed, and exported from China. 6 Following the title page, as in most Western books, this publication contains the standard copyright notices recognizing the copyright holders (the author and photographer) and an express warning not to reproduce the book.7 On the page opposite the title page is a phrase with its Chinese translation: "May you enjoy good fortune as expansive as the Eastern Sea, and longevity as long as the Southern Mountain." 8 There is much that can be inferred from this copyright acknowledgement and the corresponding message, whether or not the author acted purposefully in this regard. The author could be using the copyright notice not only to protect her property, but also to imply that copyright enforcement will grant "longevity"; she is even wishing the reader "good fortune." 9 Although the author has not been isolated from the Western world as many in China have been, 10 it is clear that she is addressing both Western and Chinese readers in her request to honor the copyright of her book and refrain from making unauthorized copies.

The second is director Zhang Yimou. ${ }^{11}$ His film Hero has been called an attempt "to explore and develop a better understanding of the Chinese concept of a hero." 12 At the film's world premiere in China in October 2002, an executive from the film's Chinese distribution company announced: "We are showing this preview for your enjoyment

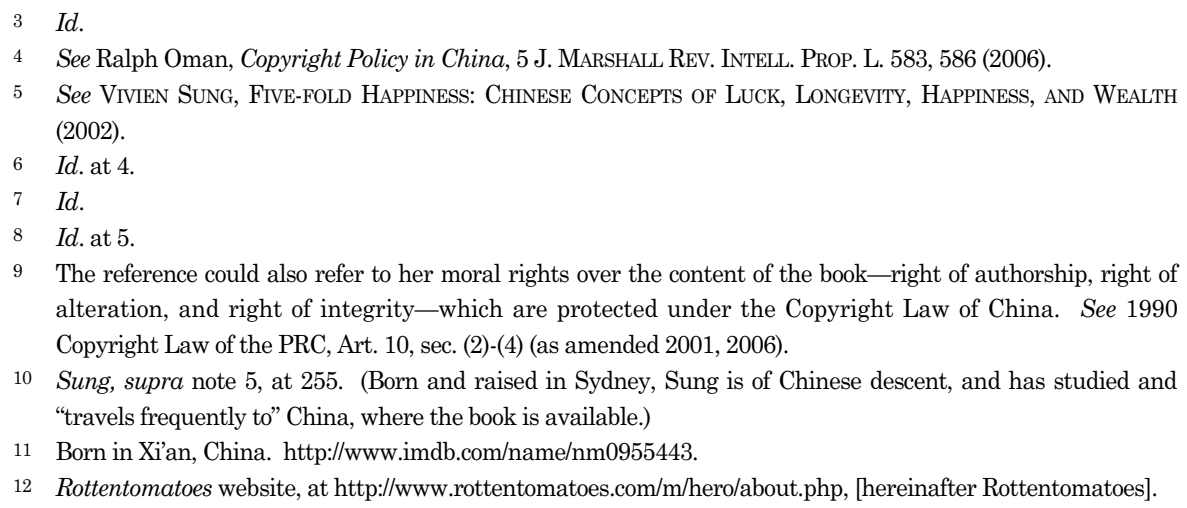
alteration, and right of integrity - which are protected under the Copyright Law of China. See 1990 Copyright Law of the PRC, Art. 10, sec. (2)-(4) (as amended 2001, 2006).

10 Sung, supra note 5, at 255. (Born and raised in Sydney, Sung is of Chinese descent, and has studied and "travels frequently to" China, where the book is available.)

11 Born in Xi'an, China. http://www.imdb.com/name/nm0955443.

12 Rottentomatoes website, at http://www.rottentomatoes.com/m/hero/about.php, [hereinafter Rottentomatoes]. 
tonight ... I plead with you to support our industry. Please do not make illegal copies of this film." 13 In addition to the warning, the audience members were videotaped as they walked into the theater through metal detectors and handed over their cell-phones, watches, and jewelry. ${ }^{14}$ Following that successful premiere and a lucrative run in China, the film earned approximately \$55.6 million in its first month in the United States in August 2004, nearly 22 months after it opened in China. 15

The third is pop music star Jacky Cheung, who has been called "incontestably the most famous and successful recording artist in Cantonese pop's short history." 16 His 2007 world tour included performances in Las Vegas, Atlantic City, and more than a dozen cities throughout China.17 An avid anti-piracy advocate, Cheung asked his fans "to stop putting MP3 files on the net. This is killing the future of music creation. It is going to affect everyone and not just the artists themselves." 18 His albums have routinely sold millions of copies, totaling more than 25 million sales. ${ }^{19}$ Because of his success, his record label, Universal Asia, has recorded and released much more music from Asian artists, most of whom will not be successful, but will bring diversity to the Chinese music scene. ${ }^{20}$ Although he expresses his creative thought through his performances, which could provide much of his income, Cheung still advocates protection of his recorded works for artistic and entrepreneurial reasons.

With the wishes of these creative people in mind, it is difficult to grasp the concept that China would not want to abide by international copyright norms to nurture the cultural sector of the country and inspire new artists. But as Peter Navarro, Professor of Business at the University of California, Irvine, explains, there is a climate in China in which piracy and counterfeiting are not only tolerated, but also "wholeheartedly embraced" by much of the population. 21 At the same time, there has been an indefatigable devotion on behalf of copyright holders, cultural theorists, and

13 Michael Schlesinger, Keynote Address to the Asia Pacific Entertainment and Media Summit 2006 (Nov. 6 , 2006) available at http://www.s3law.com/PDFFiles/MNSAPEMpresentationNovember2006110706.pdf, quoting Joseph Kahn, The Pinch of Piracy Wakes China Up On Copyright Issue; It's More Than a Trade Dispute When the Victims Are Chinese, N.Y. Times, Nov. 1, 2002, AT C1.

14 Id.

15 Rottentomatoes, supra note 12.

16 Hong Kong vintage pop radio website, at http://www.hkvpradio.com/artists/jackycheung/.

17 http://www.jackycheungworldtour.com/en/.

18 Jacky Cheung, Musicians speak out 5 IFPI NETwORK (newsletter of the international recording industry) 9, Apr. 2000, available at http://www.hitechuniverse.com/contents/industryresearch/industryresearch/AntiPiracy\%20Research/Research/IFPI\%20newsletter5.pdf.

$19 \mathrm{http} / / / \mathrm{www}$. artistdirect.com/nad/music/artist/bio/0,513900,00.html. (This figure does not include sales of pirated music, but most of Cheung's success happened before the digital age.)

20 The recording industry uses profits from successful recordings to subsidize "85 percent of recordings [that] fail to make a profit.” M. WiLliam KRASILOvsKy \& Sydney Shemel, This Business of Music 69 (2003). 
entrepreneurs to find "imaginative ways" of convincing people in China to enforce its copyright regime. 22 This article is one such attempt.

Rather than through the threat of trade sanctions and emphasis on the positive effects on commerce, copyright enforcement could be encouraged through a cultural policy, as some have envisioned copyright in the United States, albeit unofficially and usually from those outside of the judicial system. There are many ways in which such policy could be prescribed, but the message should be one in which culture, rather than business interests, should be the beneficiary of such intangible property rights.

The World Intellectual Property Organization (WIPO) divides IP into two categories: industrial property, which includes patents, trademarks, and trade secrets; and copyrights, which includes all artistic works - literary, visual, and musical.23 Until relatively recently, discussions over copyrights have not usually included industrial applications. ${ }^{24}$ And many have asserted that further separation between these two categories is needed to categorize "borderline subjectmatters that fit imperfectly" as either art or industrial property. 25 A cultural policy - in China or one that transcends borders - could be designed to include all categories of IP. While this article could be interpreted to be an instrument to advocate that all aspects of "creativity" and "creative thought" could be protected through a cultural policy, ministries of culture throughout the world traditionally have not been committed to protecting industrial property through cultural policy. 26 Therefore, this article focuses solely on copyright, and not other IP, as the subject of a cultural policy, although other IP rights are mentioned. Following an exploration into the reasons why China should desire a strong copyright system, this article explores copyright in China through a cultural perspective and then introduces cultural policy as an appropriate approach.

21 See Peter navarro, The Coming China Wars, Where They Will Be Fought and How They Can Be Won 27 (2007).

22 Robert Burrell, A Case Study in Cultural Imperialism: The Imposition of Copyright on China by the West, INTELLECTUAL PROPERTY AND ETHICS, at 222 (1998).

23 What is Intellectual Property?, World Intellectual Property Organization, available at http://www.wipo.int/ about-ip/en/ (last visited Aug. 20, 2007).

24 Andrew C. Mertha, The Politics of Piracy: Intellectual Property in Contemporary China 18 (2005) [hereinafter Mertha, The Politics of Piracy].

25 See J.H. Reichman, The Duration of Copyright and the Limits of Cultural Policy: An Evaluation of the Copyright Extension Act of 1995, 14 CARDOZO ARTS \& ENT. L.J. 625, 651 (1996).

26 China's Ministry of Culture does recognize all IP rights as part of its cultural education, although the Ministry does not play a role at China's patent or trademark offices. See, e.g., http://english.ccnt.com.cn/?catog 


\section{A. Is China a developing country that does not want copyright?}

Popular culture commentators and scholars alike have seemingly accepted the notion that because a substantial percentage of China's economy consists of piracy operations, China's government "has a pretty substantial motive not to do much about it." 27 This theory stems from an assumption that policy-makers in developing countries ordinarily object to strong IP enforcement, and from a supposition that China is a typical developing country. 28 Some assert that developing countries have traditionally perceived the use of IP as a means of development "regardless of who owns the property rights," 29 and therefore are less likely to enforce these rights. Entrepreneurs in developed countries, on the other hand, want IP rights, such as copyrights, enforced in developing countries so that their business ventures are not undermined by piracy and counterfeiting, in both developing and developed countries. 30 Companies foreign to China, for instance, would be more likely to do business in China if these companies could work in a familiar legal system that a strong copyright regime can provide. 31 Better IP enforcement also encourages companies from outside of China to sell, license, and transfer technology to China. 32 This results in increased exports from China, increased wages for Chinese laborers, and improvements to China's overall economy. 33

But incoming foreign firms have feared that Chinese authorities will do little to stop IP infringers who might bring revenues to local Chinese leaders through piracy and counterfeiting operations. 34 In the 1990s, Keith A. Maskus, Professor of Economics at the University of Colorado at Boulder, offered survey evidence that supported the theory that the general level of IP protection in a developing society was a "strong concern" of foreign companies in the decision to invest inside that developing country. ${ }^{35}$ This

=culaws\&file=020302\&ads=service_001 (last visited Sep. 20, 2007).

27 Larris MacFarquhar, Bag Man: Cracking down on fashion fakes, NEw YoRKER, Mar. 19, 2007, at 132 (noting that "[s]ixty per cent of counterfeits seized by U.S. Customs comes from [China]. Counterfeits account for about a fifth of the consumer goods on the Chinese market").

28 See Michael P. Ryan, Knowledge Diplomacy: Global Competition and the Politics of Intellectual Property, 5 TRIPS DiPLOMACY AND INTERNATIONAL LEGAL EXCHANGE 112 (2006).

29 See Amanda S. Reid, Enforcement of Intellectual Property Rights in Developing Countries: China as a Case Study, 13 DePaul-LCA J. ART \& EnT. L. 63, $82-83$ (2003) (citing Richard J. Ansson, Jr., International Intellectual Property Rights, The United States, and the People's Republic of China, 13 TEMP. INT'L \& CoMP. L.J. 1, 2 (1999)).

$30 \quad I d$. at 83.

31 See Kristie M. Kachuriak, Chinese Copyright Piracy: Analysis of the Problem and Suggestions for Protection of U.S. Copyrights, 13 Dick. J. INT'L L. 599, 600 (1995).

32 Id.

33 Organization for Economic Co-operation and Development, Economic Surveys: China 35-36 (2005) [hereinafter OECD].

34 Id. at 41. 
"concern" has compounded in recent years, as increases in IP enforcement send a "signal" to attract foreign direct investment (FDI) that many governments consider to be of growing importance, despite the fact that there is very little new evidence to prove that foreign companies actually respond. 36 However, there is some evidence that weak enforcement of IP rights has had an adverse effect on the development of some legitimate domestic industries in a more direct way, as pirates and counterfeiters generally do not discriminate between foreign and domestic sources of production. ${ }^{37}$ From these examples it follows that, with or without a trade agreement, it would benefit any developing country to protect local and foreign copyrights. Still, many see China as wanting to use others' IP without compensation or permission, so to boost the Chinese economy. 38

While there have been obvious problems with copyright enforcement in China, there also has been recent progress. A member of WIPO since 1980, China was finally recognized as having acceded to the WIPO Copyright Treaty as of March 9, 2007,39 and was recognized as a full member of the Treaty on June 9, 2007.40 Also in 2007, the U.S.China Economic and Security Review Commission reported "encouraging signs of increased cooperation" between authorities in China and the United States in the pursuit of Chinese copyright and trademark infringers. 41 However, progress has not been substantial enough for the United States government, which in April 2007 filed a complaint for what United States Trade Representative (USTR) Susan Schwab described as copyright "deficiencies in China's legal regime." 42 The Chinese government reacted

35 see Keith E. Maskus, The Role of Intellectual Property Rights in Encouraging Foreign Direct Investment and Technology Transfer, 9 DukE J. Comp. \& InT'L L. 109, 132 (1998). [hereinafter Maskus, The Role of Intellectual Property Rights] "Survey evidence points to multinational enterprises placing more importance on IPRs in deciding on FDI programs." (Maskus cites Edwin Mansfield, Intellectual Property Protection, Foreign Direct Investment, and Technology Transfer 19-21 (Int'l Fin. Corp. Discussion Paper 19, 1994)).

36 See Kieth E. Maskus, Intellectual Property Rights and Foreign Direct Investment, Centre for International Economic Studies Policy Discussion Paper No. 934, 9 (2006), available at http://papers.ssrn.com/sol3/papers. cfm?abstract_id=231122.

37 Roughly 25 percent of Chinese software companies regard piracy as "a major barrier to the development of the country's software industry." See Kong QINGJIANG, WTO, INTERNATIONALIZATION AND THE INTELLECTUAL Property Rights Regime in China, 125 (2005), citing John Wong \& Wong Chee Kong, China's Software Industry (I): On the Fast-Track, EAI BACKGRound BRIEF No. 117, 8 (Mar. 26, 2002).

38 See Peter K. Yu, Four Common Misconceptions About Copyright Piracy, 26 Loy. L.A. InT'L \& ComP. L. REv. 127, 141 (2003).

39 World Intellectual Property Organization (WIPO), available at http://www.wipo.int/edocs/notdocs/en/wct/ treaty_wct_66.html.

40 Id.

412007 Report of U.S.-China Commission, supra note 2, at 33, citing Federal Bureau of Investigation, Los Angeles Division Press Release, July 23, 2007.

42 CCN.com, China slams U.S. trade complaints, April 10, 2007, available at http://www.cnn.com/2007/ POLITICS/04/10/china.trade/index.html. 
to the complaint by expressing "great regret and strong dissatisfaction" 43 with the United States and proved its dedication to enforcing copyrights by burning millions of pirated compact discs. ${ }^{4}$ Although China has been cautious about blatantly disregarding IP enforcement requests from the United States, 45 agreements to strengthen IP enforcement have been seen as "concessions," because that is the typical response from developing countries.46 While officials from the People's Republic of China (PRC) have claimed a "commitment to international standards," China has on several occasions only "narrowly averted" punitive trade sanctions by the United States and only at the "last minute." 47

In these negotiations, Chinese officials have only reluctantly assented to improve enforcement of anti-piracy laws, a process in which these officials have shown "anger and frustration," at the perceived "meddling in internal affairs" by the United States. 48 The United States, in turn, often attacks China for only making token gestures in fighting piracy and enforcing a legitimate copyright regime.49 UCLA Law Professor Randall Peerenboom brazenly blames China for playing a "leading role" for developing countries in defying American interests with respect to IP.50 Peter K. Yu, Director of the Intellectual Property Law Center at Drake University Law School, argues that China's defiance is merely a reaction to the way Western organizations "ignore the diverging conditions, needs, and aspirations" of China, because it is "less developed." $51 \mathrm{Yu}$ demonstrates his point with examples of bad press that the World Trade Organization (WTO) received about its decision-making process being "insensitive, undemocratic, and opaque to outsiders." 52 The result: enforcement policies have fostered resentment among Chinese people of Westerners and seemingly Western policies such as

43 Id.

44 China sets fire to pirated goods in latest crackdown, Yahoo News, available at http://news.yahoo.com/s/ $\mathrm{nm} / 20070414 /$ media_nm/china_piracy_dc.

45 See Randall Peerenboom, The Fire-Breathing Dragon and the Cute Cuddly Panda: The Implication of China's Rise for Developing Countries, Human Rights, and Geopolitical Stability, 7 CHI. J. INT'L L. 17, 38-39 (2006).

46 See Silke von Lewinski, International Copyright Over the Last 50 Years-A Foreign Perspective, 50 J. COPYRIGHT SOC'Y U.S.A. 581, 586 (2003).

47 Michael N. Schlesinger, A Sleeping Giant Awakens: The Development of Intellectual Property Law in China, 9 J. CHINEsE L. 93, 99 (1995). Schlesinger offers examples of negotiations in 1992 and 1994 in which IP agreements were made at the "last-minute."

48 See Kim Newby, The Effectiveness of Special 301 In Creating Long-Term Copyright Protection for U.S. Companies Overseas, 21 SyRacuse J. INT'L L. \& CoM. 29, 44 (1995).

49 David Barboza, China Moves to Refurbish a Damaged Global Image, N.Y. TIMES, JuLY 29, 2007, at 6.

50 Peerenboom, The Fire-Breathing Dragon, supra note 45, at 38-39.

51 See Peter K. Yu, How the International Intellectual Property System, meant to Create Global Harmony, has Created Conflict Instead (Nov. 14, 2002), available at http://writ.news.findlaw.com/commentary/20021114 yu.html. (last visited Dec. 15, 2007).

52 Id. 
copyright. 53

The concern of Chinese people only holds if one accepts the premise that China is a typical developing country that should be treated differently from developed countries with respect to copyright because China's responsibilities differ from those of Western countries. 54 In contrast to this premise, Ralph Oman, former United States Register of Copyrights, asserts that China should not always be classified as a "developing country," in that it does not face the same "overwhelming problems of disease, malnutrition, and illiteracy" that the least-developed countries face. 55 Many share Oman's point-of-view. Robert B. Zoellick, President of the World Bank, called China a "middle income" nation that is "prospering over all" despite a high-level of poverty in some areas. 56 The position that China is thriving economically57 - and, therefore, should desire and implement the functioning, comprehensive copyright system of a developed country - has much empirical support. China is the world's third largest trading power. 58 In addition, the USTR reported that China has "an increasingly fast growing middle class," with the fourth largest export market for the United States.59 And the USTR has praised China for its position as a global trading power with the ability to "ensure the continued health of the global trading system." 60

Scholars have asserted that China can only continue to thrive economically if it imposes strong legal reforms to establish rule of law.61 With respect to IP laws, China has long earned praise. In 1994, during early stages of China's rapid economic development, Arpad Bogsch, Director-General of WIPO, commended China as one of the most advanced countries with significantly advanced IP legislation. 62 Today, most legal experts consider China's IP laws to be good, although most agree there could be

See Peter K. Yu, Still Dissatisfied After All These Years: Intellectual Property, Post WTO China, and the Avoidable Cycle of Futility, 34 GA. J. INT'L \& Comp. L. 143, 150 (2005).

55 Oman, supra note 4, at 587.

56 Steven R. Weisman, Zoellick Defends Aid for Nations in "Middle," N.Y. TIMES, Oct. 11, 2007, at A16. (The World Bank in December 2007 reported China's purchasing power at about 40 percent less than the Bank stated in October 2007. Keith Bradsher, A Revisionist Tale: Why a Poor China Seems Richer, N.Y. TIMES, DEC. 21, 2007, at C1.) ted States Trade Representative Report, U.S.-China Trade Relations: Entering a New Phase of Greater Accountability and Enforcement 3 (Feb. 2006).

59 Id.

60 Id. at 11.

61 See Randall Peerenboom, China's Long March Toward Rule of LaW 450 (2002).

62 See Patrick H. Hu, "Mickey Mouse" in China: Legal and Cultural Implications in Protecting U.S. Copyrights, 14 B.U. INT'L L.J. 81, 95 (1996), quoting Arpad Bogsch, Information Office of the State Council of the People's Republic of China, Intellectual Property Protection in China, Beisng Rev., June 20 -26, 1994, at 6. 
improvements. ${ }^{63}$ However, critics have argued that as good as China's laws are, they are worthless if ignored by the populace in an environment with an underdeveloped rule of law. 64 Refusal and inability to enforce its laws is largely considered one of China's most notable problems. 65 Still, very few have made the point that China's government is utterly incapable of enforcing IP laws. In 1996, even though China was at a less-developed stage than today, analyst James Shinn called the Chinese government's excuses "laughable" for refusing to shut down piracy operations.66 More recently, U.S.-China Economic and Security Review Chairman Larry M. Wortzel demonstrated this point when he said "The fact that products with the Beijing Olympic logo have been well protected in China shows that China can enforce laws when the government sees it in its interest to do so." 67

\section{B. Is copyright good for China?}

Exactly when it is in China's "interest to do so" has been at the crux of many debates. While there have been conflicting viewpoints on the value of copyright enforcement depending on the source of copyrightable material, most have agreed that it would be unrealistic for Western governments to ignore piracy in China as it exports unyielding quantities of pirated goods.68 According to Daniel Gervais, Professor of Intellectual Property and Technology Law at the University of Ottawa, it may be difficult to gauge whether increased protection of copyrights and enforcement against piracy will inevitably lead to increased FDI or immediate economic progress, but it is certain the cultural industries will suffer without copyright protection. 69 With respect to cultural products such as literature, films, and music, Maskus agrees that "the gains generated by establishing sufficient protection are 'unambiguous'." 70

63 Mertha, The Politics of Piracy, supra note 24, at 222.

64 "China today remains ambivalent about formal legal rules and the rule of law." Margaret Y. K. Woo, Law and Discretion in Contemporary Chinese Courts, in The LIMITS of THE RULE of LAW IN ChINA 184 (Karen G. Turner, James V. Feinerman, \& R. Kent Guy eds., 2000).

65 See Dingjian Cai, Development of the Chinese Legal System Since 1979 and its Current Crisis and Transformation, Cultural DyNamics 135-166, 145 (1999).

66 Yu, Still Dissatisfied, supra note 53, at 155.

67 China's Enforcement of Intellectual Property Rights and the Dangers of the Movement of Counterfeited and Pirated Goods into the United States, Hearing Before the U.S.-China Economic and Security Review Commission, 109th Cong. (2d Session) 6, June 7-8, 2006, available at http://www.cmpi.org/ viewstddoccontent.asp?detailid=68\&contenttypeid=8 [hereinafter 2006 Hearing].

68 Burrell, supra note 22, at 221.

69 See Daniel Gervais, TRIPS and Development, in Intellectual Property, Trade and Development 4 (Gervais ed, id. 2007).

70 Id. at 34, citing generally Keith E. Maskus, Strengthening Intellectual Property Rights in Lebanon, in Intellectual Property and Development, in InTellectual Property and Development 286 (Carsten Fink \& 
Many have rationalized the desire to overlook IP infringement because they believe goods and services that are generally perceived as societal necessities, such as food and medical treatment, should be held in higher regard than intangible properties such as art and music. Historical reasons involving an American puritanical past may account for much of this school of thought, but there also may be a global tradition of designating copyrighted works not as cultural treasures and instruments of innovation, but as luxuries with little public value outside of the revenues they bring large businesses. In the United States, for instance, the actual creators of works are generally in inferior bargaining positions to those who operate businesses, such as record labels.71 Therefore, because many artists - except for those who are extremely successful-are subservient those who control the market of that artform, copyright in the United States appears to operate as means to propel business interests, rather than as a cultural tool.72 The United States Chamber of Commerce, in a 2006 report that found that ineffective protection of all IP rights is its most pressing concern with respect to China's implementation of its WTO commitments, summoned "U.S. business interests" - not the cultural industries - to be "vigilant against backsliding by China on its WTO commitments." 73

This does not mean, however, that trade and cultural output are exclusive from each other. Michael Hahn, Professor of Law at the University of Waikato Law School in Hamilton, New Zealand, asserts that "[t]rade and cultural diversity are not natural enemies ... [b]ut for the purposes of WTO legal analysis, [cultural] activities wear the labels 'trade in goods' and 'trade in services'." 74 From the viewpoint of trade, it appears that Americans want increased IP protection at China's expense. Gervais notes that commentators such as Suzanne Scotchmer, Professor of Economics and Public Policy at the University of California, Berkeley, have been cynical of claims that increased IP protection is desirable for countries such as China because Western companies merely want to solidify dominance over the Chinese market.75 Using IP as this "strategic

Keith E. Maskus eds., 2004).

71 see Digital Music: Problems and Possibilities (essay for conference: A Free Information Ecology in the Digital Environment, held at New York University School of Law on Mar. 30 - Apr. 2, 2000), available at http://www.law.harvard.edu/faculty/tfisher/Music.html (last visited Aug. 20, 2007).

72 see Franklin Feldman, Stephen E. Weil, \& Susan Duke Biedermann, Art LaW: Rights and Liabilities of CREATORS AND COLLECTORS 489 (1987).

73 Rossella Brevetti, Chamber of Commerce Says IPR Protection Remains Significant Concern Regarding China, WTO REPORTER, Sept. 28, 2006, available at http://subscript.bna.com/SAMPLES/wto.nsf/ 1771f224f478f1bf85256b57005dde2f/e80eb5623d285db5852571f700025039?OpenDocument.

74 Michael Hahn, A Clash of Cultures? The UNESCO Diversity Convention and International Trade Law, 9 J. INT'L ECON. L. 515, 520 (2006).

75 GERVAIS, supra note 69 , at 37. 
instrument," Scotchmer claims "each country wants the strongest possible protection in foreign countries, and the weakest possible protections for foreigners in its own domestic market." 76

Americans often chastise China for allowing piracy and counterfeiters to take away American jobs, as businesses in the United States typically lose between \$200 and \$250 billion annually to counterfeiters and pirates. 77 This statistic probably would not be persuasive in curbing the resentment the Chinese public may feel. But United States enforcement organizations such as the Strategic Targeting Organized Piracy (STOP!) initiative recognize that pirates also cause problems for the communities in Chinaeven from a trade standpoint.78 Pirates and counterfeiters generally pay no duties to the Chinese government, so the Chinese public suffers from losses of government income.79 Those who work for pirates are often exploited, as these illegal employers usually do not comply with legal working-place standards. 80 Both pirates and counterfeiters are often organized in violent gangs 81 and are often affiliated with organized criminals. 82 The Chinese Triads, for example, are criminal organizations that harm innocent Chinese citizens through murder and extortion in addition to the Chinese artists who are injured through losses from the Triads' piracy operations. 83 There is also a growing connection between terrorism and piracy. 84 For all of these reasons, copyright enforcement can be beneficial to China.

Nevertheless, a perception prevails among many consumers and scholars that weak enforcement of IP rights, particularly of foreign goods, is beneficial to consumers, and only harms "big business" in "developed countries." But, as Gervais notes, this view is only understandable "from a business standpoint." 85

76 Id., quoting SUZANNE SCOTCHMER, INNOVATION AND INCENTIVES 329 (2004).

77 The International Anticounterfeiting Coalition website: http://www.iacc.org/counterfeiting/counterfeiting. php.

78 The National Intellectual Property Law Enforcement Coordination Council, Report to the President and Congress on Coordination of Intellectual Property Enforcement and Protection (Sept. 2006).

79 United States Trade Representative 2007 Special 301 Report, Executive Summary 6 (2007) available at http://www.ustr.gov/assets/Document_Library/Reports_Publications/2007/2007_Special_301_Review/asset_up load_file230_11122.pdf (last visited Dec. 15, 2007).

80 Id.

81 Jack Bishop, Politics of Music Piracy, speech at UCLA, 5 (Annual Meeting of the Society of Ethnomusicology, Estes Park, Colo., Oct. 24, 2002), available at http://www.jackbishop.com/PoliticsofPiracy.pdf.

82 See James M. Cooper, Piracy 101, 36 CAL. W. INT'L L.J. 89, 97 (2005).

83 Reid, supra note 29, at 70, citing Get the Facts on Fakes!: Organized Crime, International AntiCounterfeiting Coalition, at http://www.iacc.org/teampublish/109_476_1676.CFM.

84 Cooper, supra note 82.

85 GervaIs, supra note 69, at 37. 


\section{Cultural Analysis of Copyright in China}

It is this "business standpoint" that is particularly relevant with respect to the nature of a copyright system as a desirable aspect of society. Copyright law operates outside as well as within a business model. It is the business model that has provoked China's uncooperative history in fighting piracy, which University of Queensland, Brisbane (Australia) Professor Robert Burrell postulates is the reason the United States "has relied almost exclusively on the use of threats and cajolements" to pressure China to enforce its IP laws. 86 While the use of "threats and cajolements" could be deemed unethical even if successful, this method does not appear to have been effective, as the aforementioned 2006 Chamber of Commerce report described the scale and scope of piracy in China as "overwhelming." 87 And the International Intellectual Property Alliance estimates that the market share of pirated movies, music, and business and entertainment software stays at about a 90 percent level in China, notwithstanding increases in the consumer buying power of the Chinese public. 88 Oman, while admitting that a "credible threat of retaliation" is justifiable, 89 recognizes that convincing the Chinese people that copyright laws can help the public and its culture should be done "with finesse and in a nonconfrontational way." 90 This article is a testimony that a cultural understanding from both sides of the Pacific is necessary to find that "non-confrontational way" of convincing everyone that enforcement of all copyrights - domestic and foreign - is indeed in China's interest.

\section{A. China's historical perception of copyright}

From a cultural standpoint, many argue that Chinese people simply perceive the concept of IP enforcement differently than those in the West.91 To evaluate this theory, an examination of "copyright" in Chinese history is warranted.

Despite the myth that the first printing press was invented by Johannes Gutenberg for production of a bible around 1450,92 historical evidence shows not only that people

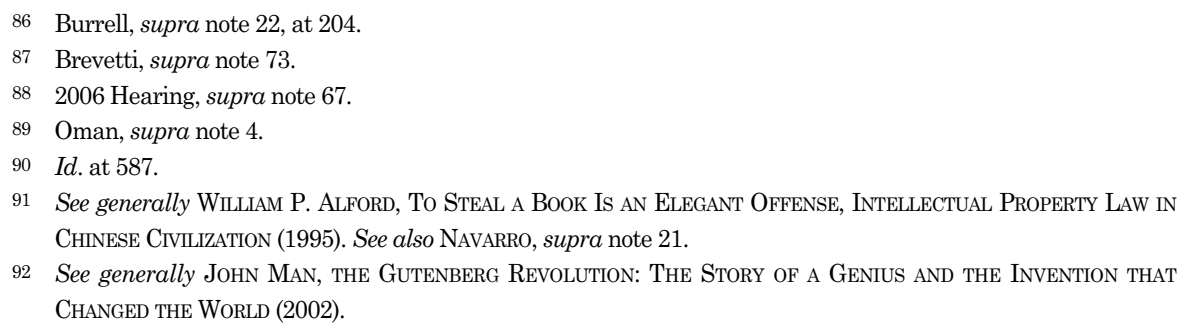


in China invented the first printing press in a primitive form during the Tang dynasty around 835 A.D.,93 but also that China was the first country to impose protections from the unauthorized copying of books and other artistic works. ${ }^{44}$ While this evidence is not suspect, there is some debate over whether these restrictions can constitute a "copyright." Chinese scholars Zheng Chengsi and Michael Pendleton, for instance, refer to archeological evidence to show that, as in the Western world, a form of copyright in China began during this early era. 95 The Chinese imperial court, for instance, oversaw regulations limiting the copying of astronomical records and calendars. ${ }^{96}$ And imprints on official documents from the Tang dynasty have been translated as "copyright markings" because they prohibited anyone but the official printer to reprint the work. ${ }^{97}$ These official reproductions were made using engraved wooden plates, as moveable type was not invented until 1042 by Bi Sheng.98

To understand why it would take more than 200 years to develop moveable type, and why copyright might take a different form in China from Europe, one can look to certain structural differences in language. Unlike English and other European languages, Chinese has always been an ideographic language; written Chinese characters express meaning, as opposed to English words, which express sound. 99 Chinese dialects are incomprehensible to someone from another part of China when spoken, yet because of the uniformity of the written characters of the language, communication is possible through writing. 100 Europeans communicate in this way with numbers; a Spanish speaker might not understand an English speaker saying the word "five," yet she will comprehend fully the written figure "5." 101 For centuries, there had been one set of written characters used to communicate throughout China, despite many spoken dialects. 102 Written language, therefore, traditionally had a diplomatic significance in imperial China as a form of official intercultural communication. 103 Furthermore, unlike in Gutenberg's language (German), thousands of characters make up the Chinese script, making moveable type impractical for those who were not

93 Burrell, supra note 22, at 200.

94 Id.

95 Alford, supra note 91, at 9, citing Zheng \& Pendleton, Copyright LaW In China.

96 Burrell, supra note 22, at 200.

97 See Peter Ganea \& Thomas Pattioch, Intellectual Property LaW in China 205 (2005).

98 Id. at 206.

99 Keith S.T. Tong \& Gregory James, Colloquial CANTONEse 1-2 (1994).

100 Frank Mou, Demystification of Mandarin Chinese, The ATA Chronicle (American Translators Association), Sept. 2007, at 10. (There are now two forms of written Chinese: "simplified," which is less than 60 years old, and "traditional.")

101 Tong, supra note 99.

102 See Scott D. Seligman \& I-Chuan Chen, Chinese at a Glance ix-xi (1986).

103 Id. 


\section{2 _ Patrick Hughes}

royalty, as it would be expensive to keep an extensive set of characters for printing.104 Europeans, in contrast, need only a few dozen characters. 105 Recognizing the structural difference between Chinese and European languages, it is easy to understand why Gutenberg's press "revolutionized the reproduction process" 106 and Bi Sheng's did not. Thus, it might not be the concept of "copyright" as the "engine of free expression" 107 that has been refuted by the Chinese populace over the centuries, but rather one can argue that it has been a perception that the structure of language has unnecessarily limited the public's use. 108 This perception is probably no longer valid, as the printing process long ago evolved to a point in which the structure of the Chinese language no longer has any bearing on the expense of the publishing process or the reproduction of any creative works.

In addition to linguistic differences, scholars offer other reasons for which regulations over published works evolved differently from the property right that was granted to authors in Europe 109 or the American incentive to "promote the Progress of Science." 110 Some view differences between Eastern and Western "copyrights" in sociopolitical terms, attributing these dissimilarities to the absence of a Western concept of finance in pre-modern China,111 a theory centered on the perception of copyright as within a business model. Others theorize that such restrictions were established through the "benevolence" of educational leaders to keep people "from being misled by 'incorrect' ways of thinking." 112 This theory cannot euhemerize any disparate views of copyright, however, because in Europe soon after Gutenberg's press, those who controlled information systems - the Church as well as guilds and trade unions - had similar intentions to censor any provocative "new learning" that may have resulted from increased publishing. 113

104 Ganea, supra note 97, at 206.

105 The alphabet, numbers, punctuation, etc.

106 See Peter K. Yu, Of Monks, Medieval Scribes, and Middlemen, 2006 Mich. ST., L. REv. 1, 11 (2006).

107 Harper \& Row, Publishers, Inc. v. Nation Enterprises, 471 U. S. 539, 558 (1985).

108 For information about how the limits of language have shaped Eastern and Western societies differently, see generally Robert Elliot Allinson, Wittgenstein, Lao Tzu and Chuang Tzu: The Art of Circumlocution, 17 AsIAN PHIL. 97-108 (2007).

109 See Carl Erik Heiberg, American Films in China: An Analysis of China's Intellectual Property Record and Reconsideration of Cultural Trade Exceptions Amidst Rampant Piracy, 15 MinN. J. INT'L L. 219, 221 (2006), citing Edward W. Plowman \& L. Clark Hamilton, Copyright: InTELLECTUAL Property in the INFormation AGE 12 (1980).

110 U.S. ConsT. art. I, $\S 8$, cl. 8 (Copyright Clause).

111 Burrell, supra note 22, at 202, citing generally PAUL Kennedy, The Rise AND FALL of the Great Powers 9-10 (1989).

112 Id. at 201.

113 Augustine Birrell, The Origin of Copyright, in Foundations of InTELleCtual Property 274 (Robert P. Merges \& Jane C. Ginsburg eds., 2004), reprinting IN LeCTUREs ON COPYRIGHT IN BOOKS (1899). 
Harvard Law School Professor William P. Alford asserts that restrictions on publishing in China until 1911 could be construed as efforts to sustain imperial power.114 His theory is reinforced by two thousand years of Confucian philosophy, which strengthened rigid social hierarchies. 115 Chinese royal authorities sought to maintain this "Confucian vision" by defining "civilization" through a set of "reciprocal, although not necessary equal, responsibilities and expectations." 116 These relationships often required ruling classes to provide paternalistic watch over all sources of information, and often involved the banning of (and even the burning of) books and the refusal to promote literacy.117 Confucian ideology also dictated that precise copying, not creativity, was "honorable and necessary" to keep society operative.118

Those who depend on the notion that Confucian influences have made copyright inoperable in China might be misguided, however, as Peter Feng, Professor of Law at the University of Hong Kong, notes:

[Copyright] policy... encourages new rights outside the scope of statutory provisions. In a nation of commercial entrepreneurs, new private property rights such as copyright... are not as intangible and remote as sometimes imagined, especially by commentators who like to blame the Confucian tradition.119

While still an important belief to many, Confucianism as a practical social management system was more or less discredited throughout the twentieth century, for relying too much on the discretion of leaders instead of the rule of law. 120 It follows that Confucian traditions probably will not serve as an impenetrable barrier to the establishment of an efficient copyright regime. More recent events must be considered.

\section{B. China in the Twentieth Century}

Because the structure of nineteenth-century Chinese society made the "copyright system" seem invisible from a Western viewpoint, there were efforts to enforce the

\footnotetext{
114 ALFORD, supra note 91, at 19-20.

115 See Lily Chang, Chinese Philosophy for the Arts and Culture in the United States, 19 J. OF ARTs MGMT \& L. 63, 64 (1989).

116 ALFORD, supra note 91, at 19.

117 Id. at 16-20. See, e.g., Derk Bodde \& Clarence Morris, LaW In Imperial China 3-32 (1967). See generally Charles Hucker, The Censorial System of Ming China (1966) (discussing intragovernment control by imperial censors and persecution of unauthorized creators).

118 See N. Wingrove, China Traditions Oppose War on IP Piracy, 38 Res. Tech. Mgmt. 3, 4 (1995).

119 See Peter Feng, Intellectual Property in China 10-11 (1997).

120 See Hu Shin \& Lin Yu-TANG, ChinA’s Own CRITICs 97-98 (1969).
} 
copyrights of foreign works through a more Western-style device.121 Piracy in China first became an issue for Americans in the mid-nineteenth century, when Chinese intellectuals began to veer from traditional Confucian teachings and acquire Western knowledge through "unhindered translations" of foreign works. 122 After several decades, Americans finally reacted with a copyright protection provision in the Commercial Treaty of 1903, which eventually resulted in China's first "official" copyright law, enacted in 1910.123 This statute was in practice until 1928, when the Nationalist government was in power and a new copyright act was promulgated. ${ }^{124}$ As part of efforts to improve American relations with China following World War II, a treaty to replace the antiquated Commercial Treaty of 1903 was enacted in 1946, which provided national treatment to one another, instead of reciprocity as the previous treaty stipulated. 125

While some copyright protection measures during the early twentieth century have been described as "forced" upon China,126 this is no reason to assume that Chinese people did not desire a copyright law. Much changed in China when it first became a republic in 1911, and many were open to new Western ideas that might protect old Eastern cultures, as Arts Manager Lily Chang explains:

[After 1911], large numbers of students and intellectuals came to the United States to study... Even though most Chinese returned to China after a few years, they played a defined role in changing the perceptions of Chinese and Americans toward each other. The students' primary goal was to acquire Western knowledge that would enable them to change their own and their country's future status. Most of them

121 GANEA, supra note 97, at 207.

122 See Thomas W.S. Huang, The Protection of American Copyrights Under Nationalist Chinese Law, 12 HaRv. INT'L L. J. 71-72 (1971).

123 Id. at 74 .

124 Id. at 76.

$125 \mathrm{Id}$. at 79. National treatment differs from reciprocity: with national treatment, a foreign work will be given the same protection in China as works from China regardless of the law in its country of origin, and with reciprocity, a foreign work will be given the protection it would in its country of origin. See H.C. Hanson, International Copyright: An Unorthodox Analysis, 29 VAND. J. TRANSNAT'L L. 579 (1996). China also entered into a national treatment agreement (with some exceptions) with other members of the Berne Convention, when China joined that agreement in 1992. "The enjoyment and exercise of these rights... shall be independent of the existence of protection in the country of origin of the work. Consequently... the extent of protection... shall be governed exclusively by the laws of the country where protection is claimed." Berne Convention for the Protection of Literary and Artistic Works, Sept. 9, 1886, revised in Paris on July 24, 1971, art. 5(2), 828 U.N.T.S. 221 (amended 1979) [hereinafter Berne Convention]. The TRIPs Agreement also contains a national treatment clause: "Each member shall accord to the nationals of other Members treatment no less favourable that that it accords to its own nationals." Agreement on Trade-Related Aspects of Intellectual Property Rights, Apr. 15, 1994, art. 3, Marrakech Agreement Establishing the World Trade Organization (1994) [hereinafter TRIPs].

126 GANEA, supra note 97 , at 207. 
came from elite backgrounds; thus they exerted considerable influence on the Chinese government after their return.127

This "trend toward Westernized so-called modernity," which followed a path set by Western Europe and the United States, only lasted for the first half of the twentieth century.128 Following World War II, the 1949 Communist Revolution, and instances of rapid inflation, progressive reforms from the Soviet Union were necessary and welcomed, and, in the 1950s, Chinese Communist Party (CCP) Chairman Mao TseTung announced that China would "lean to the side of the Soviet Union." 129 It was during this time that a new copyright law was enacted along Soviet lines.130 But the concept of property rights changed as well, as both tangible and intangible private property were no longer officially recognized. 131

Instead of an American style copyright, the Chinese government encouraged use of the "gaofei" system.132 Under this arrangement, the moral rights of the creator were recognized and an author was granted a one-time award, similar to the remuneration system in the Soviet Union at the time.133 There was some enforcement of copyrights, especially in the form of moral rights arbitration and the reporting of grievances concerning remuneration, but this was rare. $134 \mathrm{Yu}$ blames the absence of copyright enforcement during this time on the communist process of "mass indoctrination," during which Chinese people developed "strong nationalistic and xenophobic attitude[s]" toward Westerners and foreign concepts.135 It is no surprise then that rejection of a copyright system would emerge because "owning property [was] tantamount to sin" during this era. 136

Throughout Mao's reign (from 1949-76), authors could create innovative works, but

127 Chang, supra note 115, at 67.

128 Katie Lula, Neither Here Nor There, but Fair: Finding an International Copyright Legal System Between East and West, Past and Present, 8 Asian-PAC. L. \& POL'Y J. 96, 120 (2006).

129 See Wen-Hui Tsai, Class Struggle and Deviant Labeling Mao's China: Becoming Enemies of the People 72 (2001).

130 Burrell, supra note 22, at 204, citing generally WILLIAM E. ButLER, SoviET LAW 197-199, 387-388 (1988).

131 Harry Hillman Chartrand, Intellectual Property Rights in the Postmodern World, 25 J. of Arts Mgmt, L., \& Soc. 306, 314 (1996).

132 FENG, supra note 119, at 49.

133 Chartrand, supra note 131.

134 GANEA, supra note 97, at 208.

135 See Brent T. Yonehara, Enter the Dragon: China's WTO Accession, Film Piracy and Prospects for the Enforcement of Copyright Laws, 9 UCLA ENT. L. Rev. 389, 402 (2002), citing Peter K. Yu, Piracy, Prejudice and Perspectives: An Attempt to Use Shakespeare to Reconfigure the U.S.-China Intellectual Property Debate, 19 B.U. INT'L L.J. 1, 33 (2001).

136 See Peter K. Yu, The Copyright Divide, 25 CARDozo L. Rev. 331, 361 (2003). 
only for the public good and not primarily for the purpose of generating economic benefit for the copyright holder outside of the one-time remuneration, thus there was little incentive to create works that might have a long-term impact.137 But at the early stages of its development, the CCP was looking for new ways to generate creativity and become "enlightened," as Mao stated in 1940:

\begin{abstract}
Not only do we want to change a China that is politically oppressed and economically exploited into a China that is politically free and economically prosperous, we also want to change the China which is being kept ignorant and backward under the sway of the old culture into an enlightened and progressive China under the sway of a new China. Our aim in the cultural sphere is to build a new Chinese national culture. 138
\end{abstract}

The new communist government was not open to "a business model," but Mao's speech shows that people were still looking to strengthen their national culture and they recognized that their ways were "being kept ignorant and backward." 139 Mao also said that " $t]$ he Chinese learned a good deal from the West," 140 even though, in the same speech, Mao added that the "fond dreams" of learning from Westerners were shattered by "[i]mperialist aggression." 141

Despite the Chinese government's outward opposition to private property and its xenophobic practices, it would erroneous to state that the CCP has been staunchly against a strong copyright regime. In the early days of the founding of the PRC, Chinese leaders thought of the Soviet-styled copyright reward system as "a building block" to a future socialist legal system. ${ }^{142}$ But the CCP came to power in a completely different fashion than communists in the Soviet Union. 143 Because China's industrial sector was still immature during the first part of the twentieth century, the industrial worker, who usually leads a communist-based revolution, was not a significant contributor to the Revolution of 1949.144 Instead, peasants led the revolution to its

\footnotetext{
$137 \mathrm{Hu}$, supra note 62, at 104.

138 See LoIs WheEler SNow, China ON STAGe 4 (1972).

139 Id.

140 See Mao Tse-Tung, On the People's Democratic Dictatorship (June 30, 1949), in Four SeleCted Works OF Mao Tse-Tung, 411, 413 (1975) [hereinafter Mao, On the People's Democratic Dictatorship].

141 Id. Although Mao was critical of the West, he appeared to do so reluctantly and even appeared to admire Westerners. ("Why were the teachers always committing aggression against their pupil?" he asked.)

142 See Xiaoqing Feng, Lihua Yang, \& Frank Xianfeng Huang, Awakening of a Sleeping Dragon: The Evolution of Copyright Conception in China, 51 J. Copyright Soc'Y U.S.A. 615, 635 (2004).

143 See Kenneth Lieberthal, Governing China 39-56 (2D ED. 2004).

144 TsAI, supra note 129 , at 73.
} 
success. 145 From this "rural-based revolution," the $\mathrm{CCP}^{\prime}$ s leaders had a determination and seductiveness over their followers that has been described as "distinctly unMarxist," 146 and, hence, not always in line with their European counterparts.

On the other hand, even though Mao said that it was naïve to want "help from the British and U.S. governments," 147 many still looked to the West for guidance on ways to promote creativity. During Mao's time as Chairman of the CCP, foreign works of art and literature were encouraged to be used in China.148 Mao "repeatedly voiced" his opinion that China needed to "assimilate a good deal of foreign progressive culture." 149 More importantly, beginning with Mao, Chinese people began to recognize that Asian values and Western values are not necessarily different at their cores, especially with respect to the promotion of arts and culture.150

\section{China's Ministry of Culture}

Governmental responsibilities for the promotion of arts and culture typically belong to a country's ministry of culture.151 The Ministry of Culture in the PRC was the home of the first Chinese copyright office, formed just after the Ministry was founded following the 1949 Revolution. 152 The Ministry drafted two documents in 1957 to form the basis for a full copyright system, but these plans were never implemented.153 Instead, the Ministry supervised the aforementioned gaofei system, distributing "extra" income to creative people outside of their employment within their "work units" ("danwei"),154 which, during the 1950s, was often the vehicle for the issuance of state permissions for the granting of housing and economic opportunities, for instance.155 However, even the limited "rights" applied through the gaofei system became warped under political agendas, and were gradually curtailed during the late 1950s and '60s.156 In 1961, for

\footnotetext{
145 Id.

146 Lieberthal, supra note 143, at 39.

147 Mao, On the People's Democratic Dictatorship, supra note 140, at 417.

148 See Dietrich A. Loeber, Copyright Law and Publishing in the People's Republic of China, 24 UCLA L.REV. 907, 908 (1977).

149 Id. quoting Mao Tse-Tung, On Literature and Art 18, 74, 121 (1967).

150 See Amanda Sen, Development as Freedom 244-45 (1999).

151 Webster's World of Cultural Policy, available at http://www.wwcd.org/policy/policy.html\#DEF [hereinafter World of Cultural Policy].

152 Burrell, supra note 22, at 205.

153 Id.

154 Feng, supra note 119, at 49. See also LIEBERTHAL, supra note 143, at 184 (for a description of the work unit system).

155 PRC AIDS: Advice For U.S. Collaborators, available at http://www.usembassy-china.org.cn/sandt/hivcollaborations.html (last visited Dec. 15, 2007).

156 ALFORD, supra note 91, at 63.
} 
instance, the process of remuneration according to number of books was replaced with a system for rewarding the quality of books, which Alford holds "presumably mirrored the Communist Party's political agenda." 157

This process was short-lived, however, and in 1966 the Great Proletarian Cultural Revolution brought significant changes, including the suspension of all remuneration for creative works, which dashed any hopes for a legitimate copyright system. 158 Michael Keane, Professor of Research at the Queensland (Australia) University of Technology, notes one problem that arose from the absence of a reward system during this period: "Cultural output was organized around quotes and proscribed forms... those who determined production criteria were in most cases bureaucrats with little sympathy for the autonomy of creative artists." 159 Keane notes that the concept of "innovation" was still embraced by China's socialist theorists during the Cultural Revolution period (1966-78), but they imagined it as "getting rid of the old and replacing it with the new." 160

Following the Cultural Revolution, China's public policy centered on running the state more efficiently, and, hence, did not concentrate on promoting progress or honoring authors' rights through copyright.161 To counter this, the United States began to urge the adoption of free trade agreements and even pressured China to accede to the Universal Copyright Convention (UCC) in 1979, although this was in vain.162 However, other legal reforms did ensue, creating what has been known as the "reform era." 163 True to this moniker, the government enacted 327 laws and regulations and promulgated 750 administrative laws. 164

Andrew C. Mertha, Professor of Political Science at Washington University in Saint Louis, contends that, before 1978, the legal process and any significant enforcement of copyrights was "overwhelmed by the mass campaigns that dominated political life for

157 Id.

158 Id.

159 Michael Keane, Brave New World: Understanding China's creative vision, 10 InT'L J. OF CULTURAL PoL'Y, 267 (2004).

160 Id. at 269.

161 Donald Clarke, Peter Murrell, \& Susan Whiting, Law, Institutions, and Property Rights in China, in CHINA's Economy: Retrospect AnD Prospect 42 (Woodrow Wilson International Center for Scholars, No. 129, Asia Program Special Report, 2005) available at http://www.wilsoncenter.org/topics/pubs/AsiaReport_129.pdf (last visited Dec. 15, 2007).

162 GANEA, supra note 97 , at 208.

163 See Stanley Lubman, Bird in a Cage: Legal Reform in China After Mao (1999).

164 Andrew C. Mertha, Shifting Legal and Administrative Goalposts: Chinese Bureaucracies, Foreign Actors, and the Evolution of China's Anti-Counterfeiting Enforcement Regime, in ENGAGING IN LAW IN CHINA 163 (Neil J. Diamant, Stanley B. Lubman, \& Kevin J. O’Brien eds., 2005) [hereinafter, Mertha, Shifting Legal]. 
the first twenty-five years of the People's Republic." 165 After 1978, however, the legal system became "an important goal for the top leadership." 166 It is, therefore, not surprising that the remuneration system was brought back and there were more discussions of a cultural policy that included a Western-style copyright system. ${ }^{167}$ Feng attributes the reapplication of the remuneration system directly to a trade agreement with the United States, 168 enacted in 1979 after China failed to join the UCC. The bilateral treaty required China to apply copyright protection for foreign works in exchange for "most-favored-nation" trading status from the United States, 169 although the formulation of a formal copyright law was delayed.170 It wasn't until 1984 that the Ministry of Culture issued the "Trial Regulations on Copyright Protection of Books and Periodicals." 171 In 1985, the National Copyright Administration (NCA) was established as the primary copyright organization, which reported directly to China's State Council, rather than through the Ministry of Culture.172 This created a situation in which the Ministry of Culture was no longer empowered to form and maintain the national copyright system. 173

\section{Enforcement in the Modern era}

One might presume that there was renewed optimism on the part of the United States corresponding with the move from the Ministry of Culture to the NCA in the mid1980s, because during this time the Reagan administration generally asserted that "trade will change the Chinese political system" for the better.174 In retrospect, however, the NCA does not appear to have been effective in its initial stages, as the United States government recognized when it began to threaten trade sanctions in 1988 with the

\footnotetext{
$165 I d$.

166 Id.

167 GANEA, supra note 97 , at 208.

168 FENG, supra note 119, at 49, citing Agreement on Trade Relations between the United States of America and the People's Republic of China, July 7, 1979, art. 6(5), 31 UST 4652, TIAS No. 9630.

169 Id.

170 In 1979, China's State Press and Publications Administration ("Guojia chuban ju”) required China's State Council to authorize an administrative organization to draft a copyright statute, but the drafting suffered delays due to misinterpretations of the concept of "copyright," as well as bureaucracy and concerns over regulating the publishing industry. See Mertha, The Politics OF PIRACY, supra note 24, at 120-21.

171 FENG, supra note 119, at 49.

172 China in Brief, Political System and State Structure, available at http://www.china.org.cn/e-china/ politicalsystem/ stateCouncil.htm.

173 GANEA, supra note 97, at 209.

174 Henry C. K. Liu, US, China: The politics of ambiguity, AsIAN TIMES online, available at http://www.atimes. com/china/DD24Ad02.html.
} 
Omnibus Trade Competitiveness Act.175 This statute contained the Special 301 provision authorizing the USTR to use "restrictions on market access" as a reactionary measure if IP rights were not protected in China.176 This was the first time a credible threat of retaliation could have been brought against any country if IP rights were not enforced.177 To instill even more incentive to comport with the wishes of those in the United States, a new label - "Priority Foreign Country" - was attached to the PRC, along with India and Thailand, marking a new, more serious denunciation, because in previous years there were only two less-serious watch lists. ${ }^{178}$ This new designation permitted the USTR to investigate piracy in China in an official capacity. 179 It would not be unreasonable to infer that Chinese officials, and others around the world, would perceive this unilateral measure with resentment, and perceive the United States - "with its strong bargaining position" - as having an unfair advantage in subsequent negotiations. 180

One might also presume that the United States government would have again renewed its optimism about the future of China's copyright enforcement system following the enactment of China's Copyright Law of 1990,181 but it was during this period that United States officials looked at China with increased skepticism in light of the 1989 events at Tiananmen Square.182 In fact, the USTR's first threat of sanctions following the 1991 Special 301 Report included several aspersions about China for its disregard of human rights and the country's export of nuclear technology and arms.183 China's official reaction to this criticism was again one of resentment followed by the defense that the copyright system that was "forced upon them" was "a new form of colonialism." 184

Because the bifurcated copyright enforcement system that was established under the direction of the NCA in the 1980s overwhelmed Chinese courts with an avalanche of cases corresponding with other significant reforms to the legal system, administrative procedures - typically initiated by one of the numerous ministries - were often used

175 Heiberg, supra note 109, at 225; Omnibus Trade and Competitiveness Act of 1988, Pub. L. No. 100-418, 102, Stat. 1107 (1988) (“codified as amended in scattered sections of 19 U.S.C.”).

176 Id.

177 See Graeme B. Dinwoodie, et. al., International Intellectual Property LaW and Policy, 787 (2001).

178 Id. Special 301 has three lists, "watch list," "priority watch list," and the most serious designation: "priority foreign country."

179 Id. at 784-85.

180 Id. at 792-93.

181 GANEA, , supra note 97, at 210.

182 See Connie Neigel, Piracy in Russia and China: A Different U.S. Reaction, 63 LAW \& ContEMP. Probs. 179, 197 (2000), citing Keith Bradsher, Panel Asks Bush to Cite Three Nations, N.Y. Times, APR. 26, 1991.

183 Id. 
instead of courts to combat piracy and counterfeiting in the 1990s.185 This move conformed with Article 7 of China's 1990 Copyright Law, which establishes that " $[t]$ he administration department for copyright under the State Council shall be responsible for the administration of copyright nationwide." 186 These administrative procedures became ideal as copyright enforcement became more important to China's government following ascension to the Berne Convention for the Protection of Literary and Artistic Works on October 15, 1992, and then to the UCC on October 30, 1992.187 Before entry into these treaties, judicial methods were generally used to prosecute pirates and other copyright infringers through civil law procedures. 188

Mertha holds that, while the adminstrative copyright enforcement methods were not the predominant enforcement mechanism for long (only several years), they were an enormous success, partly due to the fact that the enforcement was done at a local level.189 There are other advantages to administrative procedures that forshadow an effective cultural policy instigated through administrative legal measures: there is no sparring between litigants in a courtroom; it is fast; and administrative agencies can use discretion efficiently. 190

On the other hand, some scholars have contended that the discretionary review that administrative agencies attach to their procedures has been used most efficiently as a system of "control over information." 191 Because of the nature of China's bureaucratic clusters (called "xitong"),192 those cultural and ideological media that are protected by copyrights are subject to a more politically sensitive environment. 193 And a system that uses discretion for control over copyright ownership can also be used for political censorship. 194 During this period, for instance, the films Kundun and Red Corner were banned for their political content, and administrative officials threatened to ban Disney's Mulan, until Disney released plans to open a theme park in southern China.195

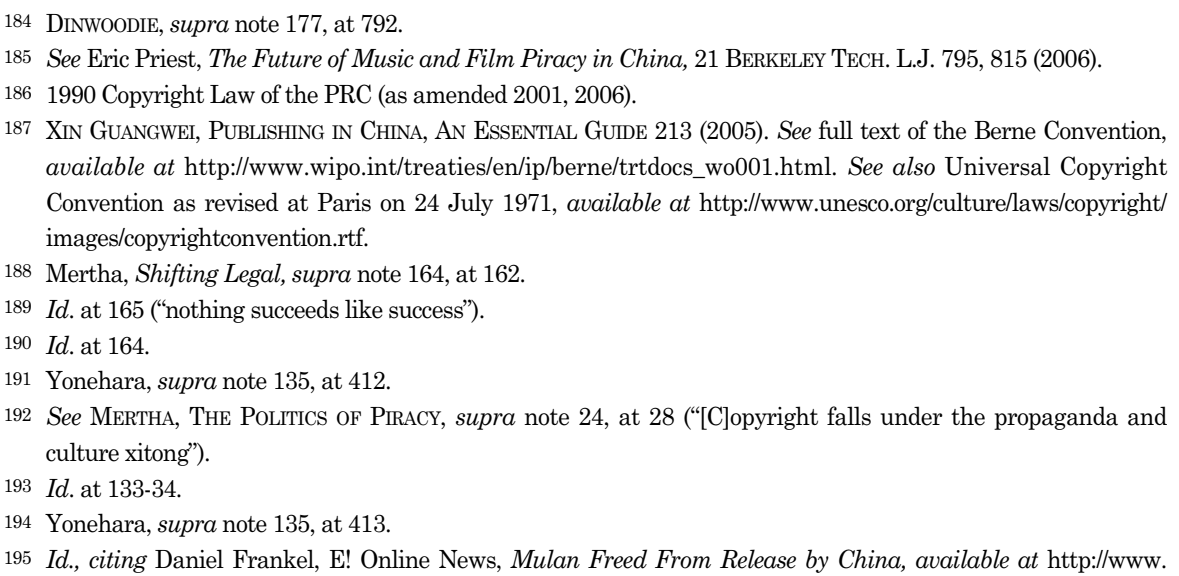


Criminal penalties began to shape the enforcement of copyrights in China in an effort to effectively deter pirates, although this move has been to date perceived as "woefully insufficient." 196 Because the 1990 Copyright Law was considered to have an overly "high level of generality" 197 with respect to enforcement measures, it was amended in 2001, on the eve of China's accession to the WTO198 and the corresponding Agreement on Trade-Related Aspects of Intellectual Property Rights (TRIPs). 199 Since accession to these treaties, China has made several changes to its copyright law and instituted numerous undertakings to increase criminal enforcement efficiency, most recently with an "Action Plan on IPR Protection" established in 2007.200 This "Action Plan" includes measures to increase the "day-to-day" enforcement of copyrights through the issuance of arrest orders and prosecutions in a more timely fashion than previously,201 but as these criminal enforcement measures appear to be ineffective, campaigns to bring administrative law procedures to the forefront of IP enforcement policy appear to be on the rise. 202

eonline.com/news/article/index.jsp?uuid=3fc858b3-7bf3-4566-8e45-d9f2a4de3ee3.

196 Priest, supra note 185, at 812. In 2006, Timothy Stratford, Assistant U.S. Trade Representative for China, indicated that criminal penalties in China were so insufficient that the government still depended on administrative channels to enforce copyrights. See Omario Kanji, Paper Dragon: Inadequate Protection of Intellectual Property Rights in China, 27 MicH. J. INT'L L. 1261, 1285-86 (2006), citing 2006 Hearing, supra note 67. Many hold that administrative measures have been effective and, in many cases, continue to be used because they are China's "preferred mode" for all legal enforcement, not just IP. Kristie Thomas, The fight against piracy: working within the administrative enforcement system in China, in PAUL TORREMANS, HAILING Shan, \& Johan ERauw eds., Intellectual Property and TRIPS COMPlince In China 87 (2007), quoting Donald Clarke, Private Enforcement of Intellectual Property Rights in China, in National Bureau of Asian RESEARCH 35 (1999).

197 Id. at 810. In addition, State Council members felt the 1990 Act was "too foreign" and-because certain provisions were tailored to honor foreign copyrights with little concern for domestic authors (even giving domestic software copyright holders shorter terms of protection (see 1990 Copyright Act, art. 7)) — unfair to domestic copyright holders. Mertha, The Politics of Piracy, supra note 24 at 130-32.

198 WTO website, available at www.wto.org.

199 Under TRIPs, "WTO members must adopt and enforce strong and non-discriminatory minimum standards of protection for intellectual property." Maskus, The Role of Intellectual Property Rights, supra note 35.

$200 \mathrm{http}: / /$ english.ipr.gov.cn/ipr/en/info/Article.jsp?a_no=67391\&col_no=102\&dir=200704\#I.

201 Id.

202 See http://english.ipr.gov.cn/ipr/en/info/Article.jsp?a_no=61796\&col_no=101\&dir=200703. 


\section{Copyright as Cultural Policy}

\section{A. Cultural Policy of the United States}

Augustin Girard of the Studies and Research Department of the French Ministry of Culture defines "cultural policy" as

[a] system of ultimate aims, practical objectives and means, pursued by a group and applied by an authority. Cultural policies can be discerned in a trade union, a party, an educational movement, an institution, an enterprise, a town or a government. But regardless of the agent concerned, a policy implies the existence of ultimate purposes (long-term), objectives (medium-term and measurable) and means (men, money and legislation), combined in an explicitly coherent system. 203

A copyright policy administered through an international cultural policy directed through China's Ministry of Culture could be seen, at first glance, as disadvantageous to Americans, and might strain relations even more between the countries, because the United States itself has no Ministry of Culture.204 This has led many to assume that the United States lacks a cultural policy, "unless the decision not to have one can, in some perverse way, be considered a policy of sorts." 205 Although some have stated that American society is too heterogeneous for a formal cultural policy,206 Margaret Jane Wyszomirski, Professor of Arts Management at Case Western Reserve University, posits that "the fact that there is no single statement of arts policy or clear identification of policy goals does not mean that there has been no policy." 207 Ruth Bereson, Professor of Arts Management at the State University of New York at Buffalo, agrees: "Whenever Americans complain that the United States has no cultural policy, I say 'Look to your Constitution'." 208 Bereson refers to the Constitution as a whole, as well as the Copyright Clause: "Congress shall have the Power: to Promote the Progress of Science... by

203 World of Cultural Policy, supra note 151, quoting Augustin GIRARD, Cultural Development: ExPERIENCES AND Policies 171-72 (1984).

204 For general ways the United States supports creativity, see National Endowment for the Arts, How the United States Funds the Arts, Jan. 2007, available at http://www.nea.gov/pub/how.pdf (last visited Dec. 15, 2007).

205 see Michael Kammen, Culture and the State in America, 83 J. of AMER. HIs. 791, 797 (1996).

206 Id. at 796.

207 Margaret Jane Wyszomirski, Federal Cultural Support: Toward a new paradigm, 25 J. OF ARTs MGMT 69, 76 (1995).

208 Ruth Bereson, Is Cultural Diplomacy a Contradiction in Terms?, Lecture for the Institute for Cultural 
securing for Limited Times, to Authors... the exclusive Right to their respective Writings." 209

George Washington University Law Professor Michael Shapiro has recognized that the Copyright Clause does form a distinctively American national cultural policy.210 This policy evolved from the time of the Framers as a content-neutral way for the government to "foster creativity for the benefit of the public." 211 As people in China have difficulty realizing the importance of copyright to their culture, people in the United States have also traditionally lacked the "knowledge and understanding of copyright as an instrument of cultural policy." 212 Shapiro quotes Abraham L. Kaminstein, former United States Register of Copyrights: "Somehow people must be made to realize that the copyright statute of a country not only shapes its cultural and intellectual development, but actually penetrates into the lives and thinking of every citizen." 213 In keeping with Kaminstein's spirit, it follows that adherence to the laws of a copyright regime becomes the responsibility of a country's leaders and educators, in the United States as well as China.

Shapiro recognizes that for the past 200 years, it has not been merely the business model, but also a rights-based rationale for creators and concern for public welfare that has provided the jurisprudential rationale for copyright in the United States.214 Shapiro notes that courts have defined three "overlapping and complementary" purposes for copyright as the cultural policy of the United States: (1) to protect authors' rights, (2) to regulate intangible property, and (3) to foster creativity for the public's benefit.215

The first of these categories - to protect authors' rights - is a reference to the natural rights protected by copyright, first recognized during the French Revolution. ${ }^{216}$ Some refer to the concept of authors' rights as protection of an author's personality, of which France has generally been considered the "vanguard." 217 This concept may seem distant from the American perception of copyright as purely an incentive stimulator, but according to Columbia University Law Professor Jane C. Ginsburg, legislators in both the United States and France roughly 200 years ago held in high regard Lockean

Diplomacy at Columbia University, Mar. 27, 2004.

209 U.S. ConsT. art. I, §8, cl. 8.

210 See Michael S. Shapiro, Copyright as Cultural Policy 16 (2001).

211 Id. at 20.

$212 \mathrm{Id}$. at 16.

213 Id. at 17.

214 Id. at 20, citing generally Ralph S. Browne, Eligibility for Copyright Protection: A Search for Principled Standards, 70 MinN. L. REv. 579 (1985).

215 Id.

216 See generally Feldman, supra note 72. 
principles that property rights such as IP "arise from one's labors." 218 In addition, Revolutionary France did not highly value the author-centrist attitudes that are considered the stronghold of protection for authors' rights, as they were considering a method for creating incentives. 219 In this category, copyright appears to be nearly universal in its application.

The second of these categories is copyright as protection of the intangible property of a work's creator. While "owning property [was] tantamount to sin" during much of China's communist past,220 the notion that all labor-and not just tangible objects - is valuable and should be rewarded was a concern of the Framers in the United States.221 While not necessarily inconsistent with communist doctrine, the concept of intangible works as private property has become what Boston University Law Professor Wendy Gordon describes as a utilitarian method of providing creative people "with a convenient mechanism to forbid copying their works, thereby ensuring that authors receive the economic benefit of their creative effort." 222 Hence, copyright assists in achieving positivism, which, while not without flaws, was instrumental in forming society in the United States and has been advocated as a means to further China's position as a functioning nation. 223

Shapiro's third rationale for copyright in the United States is as a "tool for promoting the general public good." 224 While American courts and politicians have repeatedly stated that the Copyright Clause of the Constitution provides "an incentive" for creators, 225 the system also provides an indisputable public good that is in many ways indistinguishable from the "continental copyright system" that perseveres in much of the world.226 Shapiro asserts that the copyright system is a means to reward the creative person so that society can benefit from her creative endeavors without interference from those providing private or government patronage.227 Columbia University Law Professor I. Fred Koenigsberg concurs with this position, positing that if the purpose of

217 Id. at 436.

218 Jane Ginsburg, A Tale of Two Copyrights: Literary Property in Revolutionary France and America, in RoBERT P. Merges \& Jane C. Ginsburg, eds., Foundations of Jntellectual Property 287(2004), reprinting SHERman \& Strowel Eds., Of Authors AND Origins: Essays on COPYRIGHT LAW (1994).

219 Id. at 286.

220 See Yu, The Copyright Divide, supra note 136.

221 SHAPIRO, supra note 210 , at 23.

222 Id. at 24, citing Wendy J. Gordon, Fair Use as Market Failure: A Structural and Economic Analysis of the Betamax Case and Its Predecessors, 82 COL. L. REV. 1600 (1982).

223 Peerenboom, CHInA's Long MARCH, supra note 61.

224 SHAPIRO, supra note 210 , at 24.

225 See http://www.techlawjournal.com/topstories/2003/20030115.asp.

226 GINSBURG, supra note 218.

227 SHAPIRO, supra note 210, at 25-38. 
copyright is to "promote progress" in "learning," then copyright is for the "good of all society." 228 Because patronage can effectively lead to what many consider censorship, the Framers believed that the interference of patronage should not be encouraged and the promotion of creative works is "beyond the proper sphere of government." 229 Throughout the past two centuries, the United States Supreme Court has grappled with the issue of government interference and patronage for the public good, and finally held in 1979 that "the best way to promote creativity is not to impose any governmental restrictions" on creative works. 230 There has been, however, some conflict between First Amendment rights to free speech and the Copyright Clause, which has been brought to the attention of the Supreme Court.231 Justice Ruth Bader Ginsburg finally reached an answer to the question of what limits surround the Copyright Clause as a cultural policy when she held in the majority opinion for the 2003 Supreme Court decision in Eldred v. Ashcroft, that the First Amendment protects one's own speech and "bears less heavily when speakers assert the right to make other people's speeches." 232

It is this third category that is most revealing as to why copyright should be an instrument of Chinese cultural policy. Many historians and IP scholars include only the first two of Shapiro's categories as the theoretical basis for copyright protection: to protect authors' natural rights and to regulate economic rights, which instill an incentive to promote "the Progress of Science." 233 Shapiro's third category - to benefit the public - is one that has been consistent with Confucian and socialist thought. ${ }^{234}$ It is consideration of public rights, rather than the protection of individual rights, that propels copyright law in China.235 Shapiro recognizes that this notion has shaped American history as well.

\section{B. History of Copyright in the United States}

How copyright has worked as a cultural policy in the United States over the past 200

228 I. Fred Koenigberg, Understanding Basic Copyright Law, 838 Practising LaW InSTITUTe Handbook SERIES 45,49 (2005).

229 Id. at 25 .

230 Id. at 37, referencing Mitchell Brothers Film Group v. Cinema Adult Theater, 604 F.2d 852, 860 (1979).

231 See generally Eldred v. Ashcroft, 537 U.S. 186 (2003).

$232 I d$. at 221.

233 See Jolene Lau Marshall, Online Music Piracy: Can American Solutions Be Exported to the People's Republic of China to Protect American Music?, 14 PAC. RIM L. \& PoL’y J. 189, 192 (2005), citing Jon M. Garon, Normative Copyright: A Conceptual Framework for Copyright Philosophy and Ethics, 88 CoRNELL L. REv. 1278,1293 (2003).

234 Id. at 194, citing Susan Tiefenbrun, Piracy of Intellectual Property in China and the Former Soviet Union and its Effects Upon International Trade: A Comparison, 46 BuFF. L. Rev. 1, 37-38 (1998).

235 See 1990 Copyright Law of the PRC art. 1. 
years can demonstrate how copyright enforcement for both domestic and foreign authors can aid in understanding copyright benefits. Oman recognizes that the United States government has made mistakes in copyright policies by not protecting foreign authors.236 Those who look through a cultural lens see that China today is not very different from the United States of the past, because, as many have forgotten, the United States was until relatively recently the most infamous "pirate nation" in the worldoffering copyright protection to its own nationals while neglecting to protect foreign copyrighted works. ${ }^{237}$ There is some consensus that the United States was "even worse" than China is today in overlooking piracy, and Americans still tolerate pirates at home.238

While scholars often dismiss the shameful copyright history of the United States by recognizing the progress that has been made despite modern piracy operations, 239 this can also be a point of discussion in which China can learn from American mistakes. The current Sino-American situation is reminiscent of the relationship between the United States and Europe in much of the nineteenth century. Works by copyright holders from member countries of the Berne Convention were not protected in the United States and those European countries who operated within a continental copyright system retaliated by placing restrictions on the protection given to American works. ${ }^{240}$ Rather than work together through cultural understanding, these governments clashed.

During the period when European authors were not receiving copyright protection for their works, most American authors - similar to the three Chinese artists mentioned at the beginning of this article-advocated strong copyright protection for foreign works as well as their own.241 American authors were concerned about their own finances, as well as the state of innovation and creativity at home, in a land that was being flooded with inexpensive foreign goods.242 Diplomat Max Kampelman, for instance, noted that during this time "American readers were less inclined to read the novels of Cooper or Hawthorne for a dollar when they could buy a novel of Scott or Dickens for a quarter." 243 This situation is compounded in China, where pirated cultural

\footnotetext{
236 Oman, supra note 4, at 585.

237 See Joanna Demers, Steal This Music 24 (2006), quoting Paul Goldstein, International Copyright: Principles, LaW, Practice 23 (2001).

238 Nicholas D. Kristof, Pirates and Sanctions, N.Y. TIMEs, May 24, 2007, at A27.

$239 \mathrm{Yu}$, Four Common Misconceptions, supra note 38, at 139.

240 See Stanley Rothenberg, Copyright And Public Performance of Music 71 (1954).

241 See Hamish Sandison, The Berne Convention and The Universal Copyright Convention: The American Experience, in Foundations of Intellectual Property 297 (Robert P. Merges \& Jane C. Ginsburg eds., 2004), reprinting 11 CoLUM.-V.L.A. J.L. \& ARTS 89, 90-95 (1986).

242 Id.

243 Id.
} 
products such as books, films, and music from Western countries are products from powers who brutally colonized China, and resentment from Chinese artists has emerged along racial lines. 244

\section{Constitutional Analysis}

As American cultural policy emanates from the Constitution of the United States, it follows that an examination should ensue of China's constitution, which is described as "xianfa." 245 The most recent constitution of the PRC was enacted in 1982,246 superseding three previous PRC constitutions - from 1954, 1975, and 1978.247 While many sections of these constitutions are similar in substance, the most recent constitution accentuates modernization in place of the previous emphasis on class struggle. 248 A focus on socialism has been prevalent in all versions, even dating back to China's first constitution from 1946, before the PRC was founded.249 Following the most recent amendments in 2004, the constitution expressly provides that lawful private property is "inviolable" in Article 13, and grants the right to "own and inherit." 250 Article 22 expressly dictates that the state will "promote the development of literature and art." 251 Most importantly, Article 47, commonly referred to as the provision that provides IP rights, 252 expressly provides that "the state encourages and assists creative endeavors conducive to the interests of the people that are made by citizens engaged in... literature, art, and other cultural work." 253

Articles 22 and 47 embrace Shapiro's third rationale ("tool for promoting the general public good") for copyright as cultural policy, and could assist lawmakers and plaintiffs in enforcing a copyright regime.254 One cannot necessarily depend on the strength of

244 See Frantz Fanon, The Wretched of the Earth (English trans. Constance Farrington) (1967).

245 See Donald C. Clarke, Puzzling Observations in Chinese Law, When is a Riddle just a Mistake? in C.StePhan Hsu ed., Understanding China's Legal System 103 (2003); Clarke explains that "xianfa" has connotations of a document with little importance.

246 Const. OF THE P.R.C. (as amended 2004); English version, available at http://english.gov.cn/200508/05/content_20813.htm (last visited Dec. 15, 2007).

247 Cong. Exec. Commission on China, Virtual Academy: China's Constitutional Framework at http://www.cecc.gov/pages/virtualAcad/gov/stateconst.php (last visited Dec. 15, 2007).

248 Id.

249 See W.Y. Tsao, The Constitutional Structure of Modern China 56 (1947).

250 CONST. OF THE P.R.C. art. 13 (2004).

251 Const. OF THE P.R.C. art. 22 (2004).

252 Reid, supra note 29 , at 90.

253 CONST. OF THE P.R.C. art. 47 (2004).

254 It is not surprising that China's constitution would have provisions emphasizing social responsibility, as every version has promised to support "all builders of socialism." Const. of the P.R.C., preamble, par 10. For amendments from 1988, 1993, 1999, and 2004, see http://english.peopledaily.com.cn/constitution/constitution. html. 
these provisions for utilitarian purposes, however, as the constitution has been called "toothless" by scholars and Chinese courts.255 William C. Jones, Professor of Law at Washington University in Saint Louis, cautions any reliance on the Chinese constitution, because it "seems to bear no relation to the actual government of China." 256 Jones elaborates by showing that most people in China, as well as officials, view their constitution as a general pursuit or "suggestion," much differently than most Americans view the United States Constitution.257 George Washington University Law School Professor Donald Clarke expresses his dismay over this situation:

Where the government does not operate according to the rules set forth in the constitution, that is a constitutional violation and the sign of something wrong in the body politic. Thus, the fact that the Chinese government frequently does not operate in accordance with the norms of its own constitution is a failing; it is a sign of serious political sickness; it is quite possibly even morally wrong. 258

Because the Standing Committee of the National People's Congress (NPC) follows the Soviet model, thereby interpreting and applying the constitution to legislation at their discretion rather than having the courts apply it in judicial proceedings, it is unlikely that the constitution will empower prosecutors of IP infringers.259

While it is clear that China's constitution has not yet had direct influence over enforcement of a copyright regime, Jerome A. Cohen, Professor of Chinese Law at New York University, recently recognized the "gradual emergence of constitutional law as a genuine subject and a factor to be reckoned with in Chinese politics and government." 260 Cohen is referring to the 2001 case of Qi Yuling, often called "China's Marbury v. Madison" for establishing for the first time justiciability of China's constitution.261

255 See Yanan Peng, A Sheep in Wolf's Clothing: The PRC Constitution in Qi Yuling v. Chen Xiaoqi, et. Al. 48 (2005).

256 See William C. Jones, The Constitution of the People's Republic of China, 63 WASH U. L.Q. 707, 710 (1988).

257 Id. at $710-15$.

258 Clarke, supra note 245.

259 Jerome A. Cohen, Law in Political Transitions: Lessons from East Asia and the Road Ahead for China, Congr.-Executive Commission on China Hearing *7 (July 26, 2005).

$260 \mathrm{Id}$.

261 See Shen Kei, Translations: Is It the Beginning of the Era of the Rule of the Constitution? Reinterpreting China's "First Constitutional Case," 12 PAC. RIM L. \& PoL'Y 199 (2003). The case was brought by Qi Yuling, who claimed that she had a constitutional right—not a civil right-to an education under Article 46. Chen Xiaogi applied to business school, but was refused. That school had accepted Qi Yuling, but she did not know because she did not receive the acceptance letter. Chen Xiaoqi attended, graduated, and obtained employment with Qi Yuling's name. After discovering the deception, Qi Yuling claimed that Chen Xiaoqi and the schools she attended as "Qi Yuling" violated her constitutional right to receive an education. The Supreme People's Court held that Chen Xiaoqi and others violated a fundamental constitutional right enjoyed by Qi 
Although the Supreme People's Court Vice President Huang Songyou praised the "tremendous and far-reaching importance" of the Court's decision,262 applying the constitution in this way has not been often realized as problems with judicial application look insuperable.263 Furthermore, there is still no constitutional review of government acts or statutes, so constitutional provisions that could establish elements of a cultural policy cannot be a real determinate of legislative power. 264

On the other hand, a cultural policy as Girard describes - "[a] system of ultimate aims, practical objectives and means, pursued by a group and applied by an authority" 265 - does not necessarily require direct legislative application. In this way, the constitution is not completely valueless, as it has been used as ideological symbol, educational vehicle, and starting point for policy discussions. 266 In the 1990s, for instance, China's government guaranteed constitutional protection of the "rights and interests" of foreign enterprises under Article 18 of the constitution.267 The government decided to ensure these "rights and interests" through the development of "moral education" in conjunction with other initiatives.268 Despite rather high education levels in many areas, IP rights awareness levels remain relatively low.269 The United States and other Western countries could then formally participate in a "moral education" to promote awareness of the benefits of a copyright regime as part of a constitutionally recognized cultural policy.

\section{China's Cultural Policy}

Education to bring about awareness of the benefits of strong IP enforcement can further

Yuling. Qi Yuling v. Chen Xiaoqi, et al.: Judicial Interpretation by the Supreme People's Court, available at http://www.cashl.edu.cn/search/simplequerydetail.asp?id=20060928116064519.

262 Michael C. Dorf, What a Chinese Height Discrimination Case Says About Chinese (and American) Constitutional Law (May 26, 2004), available at http://writ.findlaw.com/dorf/20040526.html.

263 Peng, supra note 255, at 52.

264 Murray Scot Tanner, The Politics of Lawmaking in China 44 (1999).

265 World of Cultural Policy, supra note 151.

266 Cohen, supra note 259.

267 Const. of THE P.R.C. art. 18 (2004). "The People's Republic of China permits foreign enterprises, other foreign economic organizations and individual foreigners to invest in China and to enter into various forms of economic co-operation with Chinese enterprises and other economic organizations in accordance with the law of the People's Republic of China. All foreign enterprises and other foreign economic organizations in China, as well as joint ventures with Chinese and foreign investment located in China, shall abide by the law of the People's Republic of China. Their lawful rights and interests are protected by the law of the People's Republic of China."

268 See Ronald C. Keith \& Zhiqiu Lin, LaW and Justice in China's New Marketplace 59 (2001).

269 Kong, supra note 37 (Kong gives evidence of low rates of patent applications in comparison with other developed countries). 
a copyright policy with some relation to an international cultural policy, enforced as trade policies have been - under the authority of the State Council of China, but with copyright responsibilities dispersed through its Ministry of Culture rather than enforced through criminal procedure mechanisms in conjunction with the NCA.270 An international cultural policy that includes enforcement of a copyright regime could be more influential than the current trade policy, because Chinese people generally do not ignore measures to reinforce China's culture as they have laws to strengthen the place of foreign businesses. Demonstrating this point on a visit to China in 2006, music producer Quincy Jones, a strong supporter of copyright enforcement in the United States, recognized the power of the arts and culture in creating harmony between nations: "The arts and entertainment bring people together. They allow the ties between us to flourish and grow, even during times when differences between governments arise." 271 In this way, copyright can be understood to be a tool to further cultural understanding through government support, rather than a tool to further business interests through government restrictions.

The State Council specifically delegates responsibilities to support-as well as instruct, administrate, and accelerate - "cultural and artistic undertakings" to its Ministry of Culture as the country's "highest cultural administrative organ." 272 While copyright enforcement is no longer predominantly within the realm of China's Ministry of Culture, the Ministry still plays a small part in educating the populace about all IP rights 273 and still performs a tangential role in copyright enforcement. ${ }^{274}$ The Ministry, for instance, still administers decisions regarding enforcement of authors' moral rights, which in China can continue after the copyright holder's death by legal heirs. 275

270 China's State Council is China's administrative arm, which establishes international trade and cultural policies and is responsible for enforcing "the principles and policies of the Communist Party of China as well as the regulations and laws adopted by the NPC, and dealing with such affairs as China's internal politics, diplomacy, national defense, finance, economy, culture and education." http://english.peopledaily.com.cn/data/ organs/statecouncil.shtml\#Bureaux. While the State Council oversees much of China's legislative drafting, and drafts China' one and five-year legislative plans, the dividing line of lawmaking responsibilities between the State Council, NPC, and the Communist Party Central Committee remains "very vaguely defined." TANNER, supra note 264, at 44-46.

271 Quincy Jones, Speech at Beijing University (May 26, 2006), available at http://uscpublicdiplomacy.com/pdfs/ Quincy_Speech-5_26.pdf.

272 The Asia-Pacific Regional Center of the Culturelink Network, available at www.culturelink.or. kr/policy_china.html [hereinafter Culturelink Network].

273 Website for China's Ministry of Culture, available at http://english.ccnt.com.cn/?catog=culaws $\&$ file $=020301 \&$ ads $=$ service_001.

274 FENG, supra note 119, at 50

275 Id. The Copyright Act of the United States only explicitly provides moral rights for visual artists during the author's lifetime. 17 U.S.C.A. $§ 106 \mathrm{~A}(\mathrm{~d})$. 
Copyright offices operate under the supervision of ministries of culture in nearly half of all countries. ${ }^{276}$ While China is not unique in having copyright administration outside the responsibilities of its Ministry of Culture,277 arts administration commentator Ruth Towse attests that copyright law should operate within a cultural policy because "copyright law influences the supply of creative works by artists and by cultural industries which use their services," 278 and a cultural ministry "should have the creative industries under its remit." 279 Gervais recognizes that official government policies are difficult to form with respect to something as amorphous as "creativity" or "innovation," 280 but he also asserts that copyright policy should be "viewed as forming part of a broader set of measures designed to optimize knowledge development and utilization. That optimization, in turn, should enhance economic growth, cultural prosperity and human development." 281

In 2000, Chinese Minister of Culture Sun Jiazheng gave a speech in New York City about China's cultural policy, which one might conclude is more open to recommendations from Americans and less defensive than the position of the Ministry of Commerce on international trade and IP protection.282 "Different cultures should learn from each other, joining hands in cooperation for mutual development," Sun said. 283 The importance of financing Chinese art for international diplomatic purposes was apparent to art critic Roger Fry in the 1930s, when he declared that people throughout the world "cannot make full contact with a [Chinese] work of art, cannot really come to terms of intimacy with its creator, until we have recognized and made allowance for this." 284 Fry illuminated what many have recognized in subsequent years: that China has an interest in creating a national identity. 285 And any reduction in

276 See Directory of Intellectual Property Offices Directory of Intellectual Property Offices, World Intellectual Property Organization, available at http://www.wipo.int/directory/en/urls.jsp.

277 See Ruth Towse, Creativity, Incentive and Reward: An Economic Analysis of Copyright and Culture in THE INFORMATION AGE 5 (2001).

278 Id. at 166.

279 Id. at 35.

280 For an examination of the struggle to define these terms, see Julie E. Cohen, Creativity and Culture in Copyright Theory, available at http://ssrn.com/abstract=929527.

281 GervaIs, supra note 69 , at 4.

282 http://english.people.com.cn/english/200009/08/eng20000908_50041.html. In contrast to the Cultural Minister's openness, Ministry of Commerce Deputy Director General Jin Xu pleaded with United States officials in 2005 to recognize China as a huge, developing country where increases in IP protection are difficult to implement. Chris Buckley, Pushed on patents, China shoves back, INT'L Herald TrIB., Jan. 14, 2005, available at http://www.iht.com/articles/2005/01/13/business/yuan.php?page=1.

283 Id.

284 See Roger Fry, Chinese Art and Architecture, in ERNEST Richard Hughes ed., ChINA Body AND Soul 31 (1938; reprint 1970).

285 Oman, supra note 4, at 585. 
China's cultural output seems to conflict with this ambition, as Chinese society is struggling to overcome what many have called "cultural colonization." 286 Martiniquian author Frantz Fanon notes that efforts to strengthen national culture can counter the racial resentment that can result from colonialism, and assist in the "fight for the liberation of the nation, that material keystone which makes the building of a culture possible." 287

In contrast to China's defensive position as a trade partner, reluctantly agreeing to accede to IP treaties such as the TRIPs Agreement in exchange for membership in the WTO and a safe haven from sanctions from the United States,288 China's current cultural policy seems to embrace the very ideals that Shapiro stresses are part of the culture policy of the United States. Furthermore, China's cultural policy seems open to reform and cultural changes that a strong copyright system can bring, as this (apparently poorly translated) excerpt shows:

The reform of Cultural system, aiming at further vitalizing cultural undertakings, stimulating artistic workers' enthusiasm, refers mainly to the reform of concrete organizational forms and management of the production relationship among cultural departments. This is the only way to prosper and develop cultural undertakings... [T] he development of cultural undertakings lacked vigor in the past. Since the reform and opening up policy was carried out, vitality has been reinforced in cultural work. ${ }^{289}$

Basic educational resources explain that piracy has been shown to "discourage creativity and investment in the cultural industries," 290 which runs in direct conflict with this aspect of China's cultural policy. Both Chinese and American consumers suffer from lack of copyright enforcement, not only from faulty goods, but also because lawful producers of copyrighted materials tend to invest in a variety of works from numerous cultural industries, some of which never become popular or secure revenues, such as avant-garde music and art-house films. ${ }^{291}$ Despite the relative obscurity of these unrenowned works, the Art Council of Europe has stated that such productions can have a "profound effect on life and emotions" and "may enrich, even define the cultural

\footnotetext{
286 World of Cultural Policy, supra note 151.

287 FANON, supra note 244, at 173.

288 Min S. Xu \& Jon F. Tuttle, China Has Joined The WTO. Are You Prepared?, available at http://library.findlaw.com/2003/ Aug/14/132989.html (last visited Aug. 20, 2007).

289 Culturelink Network, supra note 272.

290 See Council of Europe Publishing, The fight Against sound AND AUdiovisual PIRACY 13 (1995).

291 Id. at 14.
} 
fabric" 292 of a diverse and complex society, such as China's, with its rich history. As mentioned above, fostering creativity is the ultimate goal of any cultural policy, and, as Towse has noted, "[a] unifying feature of the cultural industries is that at their core is creativity protected by copyright." 293

Through this analysis of basic copyright theory, in comparison with China's ultimate cultural policy, one can make the argument that copyright can provide a "means" to further China's "ultimate purposes," and "objectives," thus providing a coherent cultural policy as described by Girard above,294 while staying consistent with the cultural policy of the United States, embodied in copyright law.

\section{E. Copyright and Communism}

One of the primary points of contention between the policies of the United States and China is their contrasting views of socialism as a desirable socio-political framework. While there can be much debate about whether copyright conflicts with "Chinese-style socialism," 295 few would argue that China is a communist utopia as Karl Marx imagined, especially in modern times. In the 1980s, Ronald Reagan, who is often called the "world's most prominent anti-communist," referred to China as a "so-called communist country" after a trip to Asia.296 Years later, Henry Kissinger said that China was never truly a communist country. 297 Benedict Sheehy, lecturer at the University of Newcastle, Australia, asserts that communism in China is far from dead, but as other values have "moved toward center stage," the role of ideological communism has become less important and the CCP has continually reinvented itself to persevere through any close scrutiny that may reveal any inconsistencies with Marxist thought.298

Whether or not Chinese society can be viewed as relatively socialist is beside the notion that Mao's proletarian philosophy was purported by Mao and others as a

\footnotetext{
292 Id.

293 Towse, supra note 277, at 35.

294 World of Cultural Policy, supra note 151.

295 CONST. OF THE P.R.C., preamble, par 7.

296 Liu, supra note 174.

297 Jim Burns, Kissinger Says China Not a Communist Country, CNSNews.com, available at http://www.cnsnews.com/ViewNation.asp?Page=\%5CNation\%5Carchive\%5C200203\%5CNAT20020305d.htm 1 (last visited Aug. 20, 2007).

298 See Benedict Sheehy, Fundamentally Conflicting Views of the Rule of Law in China and the West \& Implications for Commercial Disputes, 26 Nw. J. InT'L L. \& Bus. 225, 237 (2006).

299 Mao proclaimed that Marxism was "accepted by the majority of the people" in China as "the guiding ideology." Mao Tse-Tung, On the Correct Handling of Contradictions Among the People 241 (Feb. 27, 1957), in Stuart Schram, the Political Thought of Mao Tse-Tung (1963). Whether Mao was right is often disputed, but communism's continuing popularity in China, for good or bad, is relatively beyond dispute. See
} 
popular and influential ideology,299 and aspects of socialism - such as the subsidization of universal education, support for women's rights, and the curtailing of worker exploitation-continue to be nearly universally recognized as essential human rights.300 But many have perceived a copyright regime as conflicting with the authoritative nature of the communist state. For instance, Paul Goldstein, IP Law Professor at Stanford University and author of several books about copyright law, posits that copyright promotes "political as well as cultural diversity." 301 Neil Weinstock Netanel, Professor of Law at the University of Texas, notes that copyright can also "enhance democratic culture by highlighting the value of individual creativity" and can assist in the understanding of "the place of individual's expression within our cultural and political matrix." 302 The copyright system operates on a theory that creativity is spawned from capitalism, as creators are remunerated from their earnings in the free market. 303 In line with this theory, Netanel notes that one of the desired qualities of copyright is its ability to enable creators to disseminate cultural works "without undue reliance on government patronage," 304 thus conflicting with the concept of government administration for the public good.

China's Ministry of Culture has been a controversial governmental entity which has often instigated policies that Westerners have defined as "censorship," one of the drawbacks of government funding. 305 Controls on and restrictions of the dissemination of publications were instituted by the Ministry of Culture for many years.306 Any "[r]eactionary" or "pornographic" publications or "materials deemed harmful" were regularly confiscated by the Ministry of Culture.307 Information control by China's government remains a key concern of the foreign policy of the United States. In 2007, the U.S.-China Economic and Security Review Commission called China's censorship policies one of the "cornerstones" of China's internal security strategy, as the

East eats West website available at http://easteatswest.typepad.com/east_eats_west/2006/01/ communism_in_as.html.

300 See United Nation's Universal Declaration of Human Rights website: http://www.un.org/overview/rights. html (last visited on Oct. 20, 2007).

301 See Neil Weinstock Netanel, Asserting Copyright's Democratic Principles in the Global Arena, 51 VAND. L. Rev. 217, 230 (1998), citing Paul Goldstein, Copyright's Highway: From Gutenberg to the Celestial JUKEBOX 236 (1994).

302 Id. at 228.

303 Julie C. Van Camp, Freedom of Expression at the National Endowment for the Arts, available at www.csulb.edu/ jvancamp/freedom2.html.

304 Netanel, supra note 301.

305 Loeber, supra note 148, at 913.

306 Yonehara, supra note 135.

307 Loeber, supra note 148, at 913, citing J. WANG, A STUdy of the CRITERIA For Book Selection In CommuniST CHINA's PUBLIC LIBRARIEs 95 (1966). 
government attempts to suppress knowledge of corruption, social instability, and efforts by the government to restrain democratic movements. $308 \mathrm{Yu}$, who has been critical of the United States in its threats, also recognizes that "copyright goes hand in hand with freedom of expression," 309 as he emphasizes that authoritarian societies do not want creative people to express themselves out of fear that they may change the system and rob the status quo of their preferred lifestyle. 310 These concerns indicate that the basis of a culture policy in a communist state might not embrace the freedoms that a copyright system can evoke.

On the other hand, copyright alleviates private patronage as well as government funding, 311 an aspect of copyright that has been attractive to many liberal artists in the United States. 312 Netanel also notes that copyright "tends to undermine cultural as well as political hierarchies," which contributes to a more egalitarian society. 313 Whether the official policies of the "democratic dictatorship" 314 correspond with this notion is a decades-long debate, but there have been numerous examples of Soviet Communist Party members, most notably creative figures, who went to great lengths to enforce their copyrights in Europe and the United States.

Soviet composers Aram Khachaturian, Nikolai Miaskovsky, Sergei Prokofiev, and Dmitri Shostakovich 315 brought suit together in the United States and France to enjoin movie producers from using their music in the background for the film Iron Curtain. 316 Although these composers won their moral rights case in a French court several years later, 317 the case had to be brought under a libel action in the United States, 318 which

3082007 Report of U.S.-China Commission, supra note 2, at 259.

$309 \mathrm{Yu}$, Four Common Misconceptions, supra note 38, at 140.

310 Id. at 140-43.

311 See Thomas Babington Macaulay, A Speech Delivered in the House of Commons on the $5^{\text {th }}$ of February, 1841, available at http://www.pluckerbooks.com/works/macaulaytb/copyright/speech01.html.

312 Some of these artists include Bob Dylan and Quincy Jones, both of whom testified in Eldred, supra note 231. (The Supreme Court decided that the Congressional extension of the term of copyright protection in the United States was constitutional.) See also Tom SuTcliffe, Believing In OpERA 167 (1996) for information about patronage by "[m]oney aristocrats" and its adverse effects on the arts.

313 Netanel, supra note 301, at 272.

314 CONST. OF THE P.R.C., preamble, par 6.

315 All four were members of the Communist Party during their lifetimes, although Shostakovich did not become a member until 1960. See http://www.musicweb-international.com/Programme_Notes/shost_sym12.htm. Miaskovsky, Prokofiev, and Shostakovich were each at one time denounced by the Communist Party of the Soviet Union for being "formalist." See Kennedy Center website at http://www.kennedy-center.org/calendar/ ?fuseaction=showIndividual\&entity_id=3827\&source_type=C.

316 Shostakovich v. Twentieth Century-Fox Film Corp., 80 N.Y.S.2d 575 (Sup. Ct. 1948).

317 Feldman, supra note 72, at 436, citing Soc. Le Chant de Monde v. Soc. Fox Europe et Soc. Fox Americains Twentieth Century, (Jan, 13, 1953), 1 Gaz. Pal. 191 (1954) D.A. 16, 80 (Cour d' Appel Paris).

318 Shostakovich, supra note 316 , at 578 . 
was not at the time a member of the Berne Convention and did yet even purport to provide protections of moral rights. Furthermore many hold that the United States still does not provide moral rights, even though this is required as a member of the Berne Convention. ${ }^{319}$ Making the argument that the use of their music implies endorsement of the film, these composers nevertheless lost, because the New York Supreme Court held that "[n]o such implication exists, necessarily or otherwise, where the work of the composer is in the public domain," 320 as these works were, because the plaintiffs were "aliens" as defined in the Copyright Act of 1909, and not subject to any treaties with the United States. 321

Other communists, however, have been critical of a copyright system. Belgium scholar Pierre Recht held that Marxists have opposed the property characteristic of copyrights since the 1840s. ${ }^{322}$ Marx and Friedrich Engels wrote in their extremely influential Communist Manifesto that communist theory could be "summed up in a single sentence: abolition of private property." 323 And China's Young Communist League, which is a major source of the $\mathrm{CCP}^{\prime} \mathrm{s}$ new members, explicitly requires members to "pursue no private interests." 324 However, communist doctrine might not run as opposed to certain property rights as one might expect. In addition to copyright's appeal to Soviet composers, communists have often advocated change of the unnatural state in which history has placed society - through advances in culture. 325

The market laissez-faireism that appears to have been growing in China has also provided a noticeable income gap, 326 which has influenced many to opine that the country now "resembles the worst sort of capitalism that Marx himself could have imagined." 327 It is the capitalist movement-not communist principles - that has brought into question such issues as the property rights of workers. 328 And with this

319 Berne Convention art. 6bis. See Gilliam v. American Broadcasting Companies, 538 F.2d 14 (2d Cir. 1976); Dastar Corp. v. Twentieth Century-Fox Film Corp., 539 U.S. 23 (2003).

320 Shostakovich, supra note 316, at 578. These works were in the public domain in the United States because they were not registered and had no notice, which was then required.

321 Feldman, supra note 72, at 435-36. See also United States Copyright Act of 1909, Sec. 9 (as amended 1948).

322 Id. at 444 .

323 John BarTletT \& Justin KaPlan eds., in Bartlett's Familiar Quotations 482 (16th ed. 1992), quoting Karl Marx \& Friedrich Engels, Communist ManifEsto (1848) (trans. Samuel Moore).

324 See Derek J. Waller, The Government and Politics of the People's Republic of China 46 (1981), quoting provisions from the Young Communist League charter.

325 Those who have made this argument include Aaron Copland, Woody Guthrie, Paul Robeson, and Pete Seeger.

326 In recent years, the accumulation of private wealth has become an avenue to social status, described as "an extraordinary reversal of Maoist egalitarianism." LUBMAN, supra note 163, at 119-120.

327 Tim OAKes, China's Market Reforms, in Timothy B. Weston \& Lionel M. Jensen eds., China Beyond the HEADLINES 299 (2000). 
influx of free-market capitalism, many have witnessed traumatic suppression of Chinese culture. For instance, an Irish immigrant to China expressed his dislike of the city of Shenzhen, despite (or perhaps because of) the extreme economic growth spurred by the introduction of certain free-market mechanisms.329 "There are no roots or culture," he said, describing the city as "soulless." 330 Copyright can assist in keeping society from becoming "soulless" as creative people are given remuneration for their works, which in turn promotes culture. During the Cultural Revolution, many Chinese citizens attacked "bourgeois culture" as it appeared to be dominant,"331 which could be attributed to the absence of copyright enforcement of China's artistic works. German communist theorist Herbert Marcuse called the dominant bourgeois culture that thrives in a free market "affirmative culture," which he described as "the sigh of the oppressed creature, the heart of a heartless world: the soul of soulless conditions. It is the opium of the people." 332 Not only does copyright provide soul to a "soulless" society, but the "engine of free expression" 333 that copyright provides can help those who wish to communicate their displeasure with the growing problems caused by the inflow of a market economy, such as increased crime, depression, drug use, and suicide. 334 In other words, while people are rewarded for their labor in positions outside of the creative industries, copyright can create a balance in which creative people are not pushed aside and those issues that trouble people can be publicly acknowledged.

Those who have advocated the communist movement in China have consistently described as "complicated" the social process of moving from restricting capitalist exploitation to eliminating it completely. 335 While Marxists may require the abolition of private property, it is unlikely that they would want IP - creative expressions protected by copyrights in particular - to be the first to be eliminated. What results from increased protection of creative works is a more democratic and egalitarian society than what previously existed: consistent with communist thought.

328 Id.

329 James Fallows, China Makes, the World Takes, ATLANTic MonTHLY, July/August 2007, at 59

330 Id.

331 Dictionary of Marxist Thought 110 (Tom Bottomore ed., 1983).

332 Id. at 111.

333 Harper \& Row, supra note 107.

334 See Lionel M. Jensen \& Timothy Weston, China’s Transformations: The Stories Beyond the Headlines 72 (2007).

335 See Liu Shao-Chi, Report on the Draft Constitution of the People's Republic of China, Constitution of THE PEOPLE's RePublic of China 27 (1962). 


\section{Conclusion}

The United States, and other Western countries, should now approach officials of the PRC to enforce a copyright system through an international cultural policy that includes encouragement and educational measures for people in China and the United States. It has been evident that the United States has had difficulties persuading Chinese officials through the standard "business model." What can be concluded from this analysis is that China as an entity accepts weak copyright protection in part because more developed countries expect China's government officials to react in this way. In any negotiation, one can use another's perceived situation as leverage.336 When future trade agreements come up for renegotiation, it might be in the "best interest" of developed countries to correct the Chinese official mentioned at the beginning of this article as to what could be in the "best interest" of China, without having to resort to threats of sanctions, which have caused resentment among the Chinese populace.

China's Ministry of Culture has had a notorious past. But when one considers China's culture and traditions with respect to its constitution, its laws, and its relationship with the United States, it becomes clear that copyright policy encouraged through an international cultural policy supported by the Ministry can be something that is inherently Chinese in nature, and therefore, more likely to be enforced. After all, as the history of copyright enforcement in China has shown, difficulties in enforcement of copyrights are linked to trade and business concerns, and not usually to cultural policies. Although China's artists and its people have shown hostility toward Westerners along racial lines, many have actually looked to the West for guidance, so long as it is for advice to further China's own interests. And although it has been contested, many scholars hold that China has had some success experimenting with different systems of IP enforcement, and copyright is not as foreign a concept to China or to its Communist leaders as some have previously believed. What has not been contested is that China has a rich history in the arts and culture, with creative forms that have been worthy of protection by anyone's standards. Protecting creativity and innovation could be seen as a popular measure, and one that the Chinese public's favorite artists and cultural personalities advocate. 